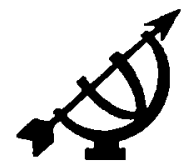

\title{
Die sakelys vir wetsteksvertolking en die epog van konstitusionalisme in Suid-Afrika'
}

\author{
Lourens du Plessis \\ Departement Publiekreg \\ Universiteit van Stellenbosch \\ STELLENBOSCH \\ E-pos: Imdp@akad sun.ac.za
}

\section{Abstract \\ The agenda for legislative-text interpretation and the epoch of} constitutionalism in South Africa

This article deals with the new demands that the advent of an era (or epoch) of constitutionalism places on the agenda of statutory and constitutional interpretation (i.e. legislative or enacted low-text interpretation) in South Africa. Three central mottfs guide the discussion:

- A self-dependent legislative text with an inherent, fixed meaning does not exist.

- The characteristic operational intent of the text genre limits the multffarious possible meanings of an enacted law-text. This confronts its interpreter with an inescapable responsibility to choose a particular meaning.

- The epoch of constitutionalism inevitably places a transformational subversion of certainties regarding statutory interpretation on the agenda of innovative legislative-text interpretation.

The jurisprudential applicability of mainly three interpretative narratives is considered, namely reflective rhetoric, deconstruction and philosophical hermeneutics.

First, the necessity for a new terminology is considered. Legislative-text interpretation is advanced as the appropriate term designating statutory as well as

1 Die finansiële ondersteuning van die Sentrum vir Wetenskapsontwikkeling (tans National Research Foundation) wat die navorsing waarop hierdie artikel gebaseer is deels moontlik gemaak het, word hiermee erken. Die standpunte hierin uitgespreek en gevolgtrekkings waartoe geraak word, is egter dié van die outeur en nie dié van die Sentrum vir Wetenskapsontwikkeling/National Research Foundation nie. 
constitutional interpretation. Despite their dissimilarities, statutory texts and the constitutional text have enough in common to be grouped together as "legislative texts", a sub-genre of law-texts in general.

Second, some of the crucial assumptions of the common-law Aiteralist-cumintentionalist) approach to statutory interpretation are subjected to critical scrutiny. The concept "intention of the legislature" is looked at in both an optimally positive and an optimally negative way.

Third, the significance for legislative-text interpretation of insights gleaned from contemporary philosophies of interpretation, is considered. These insights are the following:

Insight 1: A standard interpretation of law texts that assumes that they are independent bearers of authurity and that they derive from accepted meanings of legal concepts masks the perpetuated hegemony of dominant classes/groups/ categories in society, with an unfounded appeal to an illusory neutrality and impartiality of the law.

Insight 2: Language, as a complex system, is the source and guide of and operational space for all meaning.

Insight 3: Meaning can only be meaning-in-context.

Insight 4: Our pre-understanding not only shepherds our understanding but makes it possible. The deeper an assumption is hidden, the more intense and far-reaching is its effect on our understanding.

Insight 5: The (possible) applications of a provision of a legislative text, always pilot its interpretation. Such provision can never be understood in isolation from. or irrespective of its possible applications.

The article concludes by taking stock of the unfounded certainties about statutory interpretation it has sought to undermine and suggests the exploration of an approach to law-text interpretation that honours both the concerns of present-day philosophies of understanding and jurists' responsibility to opt for text-meanings that will optimise justice.

\section{Inleidend}

Hierdie artikel huldig Johan van der Vyver in veral twee opsigte:

- Eerstens as 'n regsfilosoof wat regsfilosofie "prakties" en werklikheidsbetrokke bedryf. Regsfilosofiese analises en modelle (in sy geval veelal dié van die Wysbegeerte van die Wetsidee van Herman Dooyeweerd) help hom om konkrete probleme in die regs- en lewenspraktyk raak te sien, te verstaan en intellektueel verantwoord te beredder. So 'n werkswyse is besonder vanpas wanneer oor wetsteksvertolking besin word

- Tweedens as 'n herout van die epog van konstitusionalisme in Suid-Afrika. Oor sy reusebydrae tot die vestiging van ons menseregtekultuur, wei ek elders 
in hierdie uitgawe uit. Hierdie huldigingsartikel probeer die verreikende implikasies van konstitusionalisme vir wets- en grondwetsinterpretasie in kaart bring. Ek probeer dus sin maak van wetsteksvertolking in 'n nuwe bedeling waarvoor Johan van der Vyver dikwels teen 'n prys 'n gewaardeerde kampvegter was.

Kortliks die een en ander oor die titel van en oogmerke met hierdie bydrae.

Oor die term "wetsteksvertolking" word in punt 2 hieronder uitgewei.

"Epog" intensiveer die idee van "'n nuwe bedeling". Vernuwende insigte, in wisselwerking met gebeure van uitsonderlike historiese belang, is epogmakend. Kousale geskiedskrywing (causal histories) beskryf opeenvolgende gebeure. Epogale geskiedskrywing, daarenteen, takseer die impak van homogeen of "eenderslykend" gestruktureerde, onderskeidende eras (soos Hellenisme, Barok, Verligting, Romantiek ensovoorts) op die evolusie van 'n kultuur en tradisie (McKeon, 1990:127-128). Konstitusionalisme in die nuwe Suid-Afrika is nie maar 'n "logies"-kousale opvolgfase ná apartheid nie. Dit is 'n epogmakende transformasie wat ons regskultuur en -tradisie onherroeplik herbeteken maar dit nie volstrek loën nie en ook nie met huitjie en muitjie trash nie. ${ }^{2}$ Wetsteksvertolking is in hierdie kultuur en tradisie ingebed en kan alleen transformasioneel herverstaan word, deur sin te probeer gee aan die dialektiek van konstitusionalisme se onherroeplik nuwe en onvermydelik kontinue momente. Die volgende drie ideëmotiewe rig die gedagtegang in hierdie artikel:

- Daar is nie so iets soos 'n selfstandige wetsteks met 'n vaste betekenis daarin opgesluit nie.

- Die veelheid moontlike betekenisse van 'n wetsteks word vanweë die kenmerkende geldingsintensie of, liewer, geldingsgerigtheld van die besondere teksgenre beperk. Dit stel die vertolker voor 'n onvermydelike keuseverantwoordelikheid.

- Die epog van konstitusionalisme plaas 'n transformasionele ondermyning van tradisionele sekerhede oor wetsuitleg op die sakelys (en takelys) van vernuwende wetsteksvertolking

Sonder om te probeer voorgee dat hulle wenners op 'n ideëparade van kontemporêre idees oor verstaan en vertolking is, word die regsgeleerde toepassingsmoontlikhede van aspekte van veral drie vertolkingsnarratiewe oorweeg, naamlik retorika, dekonstruksie en wysgerige hermeneutiek.

2 Trashing is tipiese Critical Legal Studies-terminologie wat in 4.1 hieronder enigsins nader omskryf word. 


\section{Waarom "wetstekste vertolk"?}

Omgesit in common low-omgangstaal, handel hierdie artikel (in 'n groot mate, ten minste) oor dit wat op die sakelys is vir die vernuwing van die regsgeleerde dissipline Uitleg van Wette (Interpretation of Statutes) ${ }^{\mathbf{3}}$ in Suid-Afrika. Met die inwerkingtrede van Suid-Afrika se eerste oppermagtige, beregbare grondwet op 27 April 1994, is grondwetlike uitleg/grondwetsinterpretasie/grondwetsvertolking (constitutional interpretation), heel prominent op die agenda geplaas. Hierdie besondere verbreding van die dissipline is prinsipieel vreemd aan die common law-wetsuitlegtradisie wat in 'n Suid-Afrika onder parlementêre soewereiniteit die toon vir wetsinterpretasie aangegee het. Laat daar geen vergissing wees nie: Uitleg van Wette in Suid-Afrika is van huis uit common law en Engels. L.C. Steyn (1981) se Romeins-Hollandse genealogie van die vakdissipline (kyk bv. Steyn, 1981:xxiii-xxviii) oortuig nie.

- Eerstens is die gangbare teoretiese grondaannames oor wetsuitleg in SuidAfrika (tipies common low) letterknegtig-cum-intensionalisties (kyk 3.1 hieronder). Soos in die common law-moederland, het die evangelie van parlementêre oppergesag hierdie aannames ook by ons gelegitimeer en versterk. Steyn self predik die oppergesag van die wetgewersbedoeling, mits duidelik verwoord, en sy magnum opus oor die Uitleg van Wette stem wat inhoud, styl, argumentasie en selfs struktuur betref, nóú ooreen met Engelsregtelike standaardwerke oor Interpretation of Statutes (byvoorbeeld Maxwell, 1976; Craies, 1971 of Cross, 1995).

- Tweedens verrek Steyn die begrip "ons ou skrywers" om van oral oor oënskynlik "Romeins-Hollandse gesag" bymekaar te skraap ten einde wesenlik Engelsregtelike uitlegreëls te verduidelik en te regverdig. Die Duitse pandektis, C.F. von Glück, die Italianer, Josephus Averanius, en C.H. Eckhardus, die Germanus Germanorum soos wat hy homself in sy Hermeneutica Juris noem, tel volgens Steyn byvoorbeeld almal onder Uitleg van Wette se "ou skrywers" (Van Blerk, 1984:278).

Die aanbreek van die epog van konstitusionalisme in Suid-Afrika maak 'n eensklapse en algehele breuk met die common law-wetsuitlegtradisie nóg moontlik nóg nodig nóg onafwendbaar. Kontinuïtet is 'n wesenlike faset van enige tradisie - selfs van 'n nuwe epog. ' $n$ "Skoon breuk" met die verlede is 'n pypdroom. Die nuwe grondwetlike bedeling - núút genoeg om epogmakend te wees - verg nogtans egter 'n vernuwende herkonseptualisering (en plek-plek selfs die opruim) van uitlegkundige gemeenplase soos hulle in common low Uitleg van 
Wette manifesteer (vgl. byvoorbeeld Du Plessis \& De Ville, 1993c:359-379 en Du Plessis, 1997). ${ }^{4}$

Dit is strategies gepas om hierdie vernuwing ook terminologies te probeer uitdruk. Tradisioneel word van die verstaan en toepassing van statutereg as die uitleg van wette gepraat. Dit is sinvol om "uitleg" met "vertolking" te vervang. Een betekenisnuanse van "vertolk" is "uitbeeld", "uitvoer" en per implikasie dus "lewend maak". In Afrikaans is die uitvoering van 'n musiekstuk of die speel van 'n rol in 'n toneelstuk byvoorbeeld "'n vertolking". "Vertolking" verwoord met ander woorde die twee-eenheid van verstaan en toepassing treffend (kyk ook 4.5 hieronder). 'n Soortgelyke betekenisnuanseonderskeid word ongelukkig nie in Engels altyd met twee verskillende woorde uitgedruk nie: "vertolking" in Afrikaans is ruimer en sterker as byvoorbeeld "construction" of enige ander Engelse woord wat met die verstaan (-en-toepassing) van die geskrewe of gesproke woord geassosieer word. Die ruimer en sterker konnotasie van "vertolk/vertolking" is weliswaar inherent aan "interpret/interpretation". Die regshermeneutiese onderskeidingsmoontlikhede wat Afrikaans met twee verskillende woorde bied, is egter groter.

'n Ruim konsepsie van wetsvertolking rugsteun ook 'n vrymoediger gebruik van die woord "hermeneutiek" (en sy toepaslike byvoeglike naamwoords- en werkwoordsvorme) as sinomiem vir "vertolkingskunde". "Hermeneutiek" het die nadeel van 'n historiese belading deurdat dit soms met slegs 'n bepaalde wysgerige tradisie van teksinterpretasie ${ }^{5}$ vereenselwig word (vgl. byvoorbeeld Devenish, 1992:14-18). Dit het egter ook 'n klassiek-ruimer betekenis. In die antieke Griekse mitologie was Hermes die boodskapper van die gode wat hulle wil moes vertolk en dan aan sterflinge moes oordra. "Hermeneutiek" dui dus ook vertolkingskuns in den brede aan. Daar is dus geen beginsel- of historiese rede om "hermeneutiek" vir slegs die tradisie van wysgerige hermeneutiek te annekseer nie, mits 'n mens versigtig met die antieke metafoor omgaan. Die idee dat daar 'n betekenisvolle "wil van die gode" in 'n teks aanwesig is en dat die teksvertolker 'n Hermes is wat dit uitlê en aan ander oordra, word in die meeste kontemporêre vertolkingsnarratiewe (ook dié waarop in hierdie artikel gesteun word) heftig ontken.

4 "Óök in die common law-tradısıe manifesteer", want baie uitlegadagia kom ook in ander tradisies voor; vgl. byvoorbeeld Wolff et al., (1994:334-335) se beskrywing van "Schlußverfahren bei der Auslegung und Lückenerganzung" in die Duitse reg met die common lowprosedures van ekstensiewe interpretasie (Steyn, 1981:41-54, Du Plessis, 1986:155-157). Juis hierdie universele kant aan uitlegreëls maak dit vir Stcyn moontlik om 'n Romeins-Hollandse afstamming aan Engelsregtelike reëls en vermoedens van wetsuitleg in Suid-Afrika toe te skryf en dic werke van Duitse en Italiaanse skrywers te gebruik om hom hierin te steun.

5 Op insigte waarvan ook in hierdie artikel gesteun word; kyk bv. 4.4 en 4.5 hieronder 
Dit is voorts betekenisvol om van verordende regstekste (enacted low-texts) as wetstekste (legislative texts) en hulle vertolking eerder as van wette en hulle uitleg te praat. Die verwysing na wetstekste beklemtoon, eerstens, dat wetsvertolking die verstaan en toepassing van 'n besondere tekssoort of -genre behels. Surd-Afrikaanse wets- en regsvertolkers gee tradisioneel nie genoeg erkenning aan die feit dat teksgenre bepalend is vir die manier waarop 'n mens 'n teks lees en vertolk nie. Gesproke en geskrewe tekste kan byvoorbeeld nie op dieselfde wyse benader word nie. Regstekste is geskrewe tekste - naas ander geskrewe teksgenres, soos literêre tekste (romans of gedigte), godsdienstige tekste (die Bybel, die Koran of geloofsbelydenisse), wetenskaplike tekste (vaktydskrifartikels, wiskundige formules of navorsingsverslae) ensovoorts Wetstekste is 'n subgenre van regstekste (naas gewysdes, kontrakte, testamente, verdrae, hoofde van argument ensovoorts). 'n Wetsteks is, meer bepaald, 'n geldende (oftewel positiefregtelike) regsteks wat deur 'n aantoonbare outeur ('n wetgewer of grondwetgewer) verorden (enacted) is.

Verskillende leeskonvensies geld vir 'n wet, 'n gedig en 'n Bybelteks. Van laasgenoemde twee genres word selde indien ooit gesê dat 'n mens hulle letterlik moet vertolk. Van wette egter, veral dié wat in vermeend "duidelike en ondubbelsinnige taal" geskryf is, sê juriste dit heel geredelik (en met 'n pretensie van groot tegniese kundigheid). Hinderlik aan hierdie aanspraak is die implikasie dat 'n wetsteks bloot "'n stuk taal" is en nie (soos enige ander teksgenre) taal-inaksie op so 'n manier dat aan die unieke tekswees daarvan uitdrukking gegee word nie. 'n Mens kan nie 'n wetsteks (of enige ander teksgenre) verstaan deur suiwer of uitsluitlik op die ("gewone") taal daarvan te konsentreer nie. Jy moet ook begryp waar dit vandaan kom, hoe dit funksioneer (en in watter konteks) en wat dit probeer bereik. Hierdie insig is aan twee caveats onderhewig:

- Taal bepaal die betekenis van enige teks grondliggend en deurslaggewend, maar doen dit nie as ' $n$ op sigselfstaande, neutrale betekenisgewer nie. Taal is tipies tekstaal en dus genretaal. Wetstaal is nie duidelike en ondubbelsinnige taal nie (wee die taal wat voorgee om dit te wees!) maar die taal waarin 'n eiesoortige tekssoort "konvensioneel praat".

- 'n Pleidooi dat die eiesoortigheid van 'n wetsteks vertolkingshalwe verreken moet word, is nie 'n poging om die teks eensydig onafhanklik te verklaar en dus los te maak van die ryk netwerk van betekenisbepalers waarby dit inskakel nie. Verder aan (in 3.5 en 4.3 hieronder) word geredeneer dat dit problematies is om wetstekste so te verselfstandig.

Die gebruik van die woord "wetstekste" is tweedens 'n elegante manier om gewone wetstekste (met ander woorde statute) en die grondwetsteks in één (sub-)genre tuis te bring, mits 'n mens in beginsel daarmee akkoord gaan dat daar 'n noue verband is tussen grondwetsvertolking en 
- regsvertolking in die breë (Schneider, 1963:1; Ehmke 1963:53) asook

- wetsvertolking in die besonder (Dreier, 1976:13-17).

Veral die laasgenoemde faset van hierdie siening is nie onomstrede nie. Magiera (1983:91-94) voer aan dat 'n sito-sito-gelykstelling van wets- en grondwetsvertolking té maklik uit die oog verloor dat grondwetsbepalings, op grond van hulle omvang asook hulle (relatiewe) onbepaaldheid en "onvoltooidheid", struktuurtipies van gewone wetsbepalings verskil. 'n Grondwetsteks en gewone wetstekste verskil tewens ook wesenstipies (en dus hermeneuties betekenisvol) van mekaar, in selfs méér opsigte as wat Magiera te kenne gee. So geld 'n grondwet met 'n ander soort gesag as gewone wetstekste, naamlik oppergesag. Hermeneuties benader ' $n$ mens 'n grondwet dus, anders as gewone wette, nooit met ' $n$ skeptiese nietigheidsverwagting nie, want dit is dié troefkaart in die regsisteem. 'n Grondwet is daarbenewens die "duursaamste" en moeilik wysigbaarste van alle regstekste wat hulle onstaan aan 'n aanwysbare wetgewer dank. Dit moet met tydsverloop dus só vertolk word dat dit veranderende tye en omstandighede - oftewel "present circumstances" (Du Plessis \& De Ville, 1993c: 376-377) - verantwoord honoreer.

Voor die inwerkingtrede van die 1994-oorgangsgrondwet, Suid-Afrika se eerste Grondwet met oppergesag, het Jacques de Ville en ekself 'n artikelreeks oor grondwetsvertolking in Suid-Afrika (insluitend die toentertydse TBVC-state) gepubliseer (Du Plessis \& De Ville, 1993a, b en c). Ons was krities oor 'n neiging onder Suid- en Suider-Afrikaanse howe om, in plaas van in gepaste gevalle die uitdaging van waagmoedige grondwets- en veral menseregtehandvesvertolking te aanvaar, eerder - met 'n skyn van regstegniese vernaamheid agter 'n formalistiese letterknegtig-cum-intensionalistiese benadering tot wetsuitleg te probeer wegkoes. ${ }^{6}$ Hierdie wegholhouding het in uiterste gevalle grondwetlike oppergesag geheel en al ontkrag. In Government of the Republic of Bophuthatswana and Others v. Segale (1990 (1) S.A. 343 (B.A.D.)) het die Appèlhof in 'n destydse "tuisland" byvoorbeeld bevind dat die "duidelike taal" van 'n gewone parlementswet, 'n algemeen geformuleerde, regte-verskansende bepaling in 'n oppermagtige grondwet kan troef? Wat die howe se ontkenning van die andersoortigheid van 'n grondwetsteks vir vertolkingsdoeleindes boonop vererger het, was hulle versuim om "met die jongste ontwikkelings in die algemene uitlegleer" rekening te hou (Rautenbach, 1995:23 vn 24).

Met dit alles gesê, is 'n grondwetsteks nietemin 'n wetsteks (natuurlik van 'n besondere soort) en is daar heeltemal genoeg wesenlike ooreenkomste tussen

6 Vgl. byvoorbeeld ons kritiese beoordeling van die saak van Cabinet for the Territory of South West Africa v. Chikane, 1989 (1) S.A. 349 (A) - Du Plessis \& De Ville (1993a:68-73) 
gewone wetstekste en die grondwetsteks om hulle genre-genote te maak. De Ville en ek het byvoorbeeld in die laaste aflewering van ons 1993-artikelreeks (Du Plessis \& De Ville, 1993b:359-379) probeer aantoon dat sekere metodologiese leivore vir 'n benadering tot "gewone wetsvertolking" wat ekself voorheen getrek het (vgl. Du Plessis 1986:47-60) - en, moet ek byvoeg, tans anders sou trek ook die koers vir grondwetsvertolking kan aandui.

Magiera (1983:92-95) voer twee verdere redes aan waarom hy, in die Duitse konteks, grondwetsvertolking en gewone wetsvertolking liefs uitmekaar wil hou. Eerstens sê hy dat die aanwend van standaardtegnieke by gewone wetsvertolking nie kon bewys dat 'n objektief-konsekwente vertolkingsresultaat (met die uitsluiting van 'n subjektiewe vertolkerswillekeur) bereikbaar is nie. Gewone wetsvertolking het dus vir grondwetsvertolking niks sinvol te leer nie. Hierdie kritiek is allermins ontstellend. Oor die nie-vervulling van sulke werklikheidsvreemde verwagtings hoef 'n mens nie 'n enkele traan te stort nie! Tweedens sê hy dat "gewone wetsvertolkers" in die Duitse tradisie nie die Bundesverfassungsgericht se pragmatiese, buigsame en a-dogmatiese benadering tot grondwetsvertolking na waarde kan skat nie. Dit is nogeens toe te skryf aan 'n misplaaste vertroue in die hermeneutiese sekerhede wat 'n voorspelbaar-saaklike benadering tot wetsteksvertolking kwansuis kan verseker. Sommige outeurs is trouens van oordeel dat die Duitse weergawe van regspositivistiese wetsteksvertolking heilsaam op regsekere en derhalwe "voorspelbare" grondwetsvertolking kan inwerk (vgl. byvoorbeeld Herdegen, 1990).

Vir Suid-Afrikaanse gebruik kan 'n mens veral die laaste kritiekpunt van Magiera positief omkeer. Ons grondwetlike oorgang wat onvermydelik nuwe hermeneutiese eise vir grondwetsvertolking stel, help ons om met nuwe oë na die tradisionele common law-benadening tot wetsteksvertolking te kyk en die gebreke daarin (opnuut) raak te sien. Ofskoon nie volledig nie, sal ek verder aan probeer aantoon hoekom en hoedat dit gebeur.

\section{Tradisionele common law-grondaannames oor wetsvertolking}

\subsection{Letterknegtig-cum-intensionalistiese wetsvertolking}

Die meeste regsgeleerdes, geskool in die Suid-Afrikaanse weergawe van common law-wetsuitleg, sal wetsvertolking kortweg beskryf as "'n soeke na die bedoeling van die wetgewer" (vgl. ook, heel betekenisvol, Steyn, 1981:1). Die meeste van hulle sal waarskynlik egter onseker wees oor wat vir 'n tipe verskynsel die "bedoeling van die wetgewer" presies is. Is dit "dít wat die wetgewer beveel"? Of is dit "dit wat beoog word", met ander woorde die doel van die wet? Of dui dit dalk op "die gedagtegang van die wetgewer" - dit wat die wetgewer gedink het toe die wet gemaak is? Al hierdie betekenisse van "bedoeling van die 
wetgewer", maar veral die laaste een, is problematies. In moderne wetgewingsprosesse is nie slegs 'n enkele persoon dié wetgewer nie maar word wette gemaak deur liggame wat as beraadslagingsforums funksioneer en uit meerdere verskillend denkende mense bestaan die wette. Staatsamptenare, in opdrag van politici, formuleer konsepwetgewing in die vorm van wetsontwerpe. 'n Wetsontwerp word by die wetgewende liggaam ingedien en intensief in komitees sowel as tydens plenêre sittings van die wetgewende liggaam gedebatteer. Deelnemers aan beraadslagings is politieke opponente met eie (veelal versteekte) agendas, met eie politieke beleidsrigtings ... en met 'n eie ondersteunersgehoor wat hulle moet tevrede stel. Dikwels word heftig oor die inhoud van wetsontwerpe verskil. Soms word kompromieë getref om beswaarde minderheidsgroepe tegemoet te kom. Ander kere weer seëvier die wil van die meerderheid wanneer oor 'n wetsontwerp gestem word. Aan die einde van die proses is 'n "bedoeling van die wetgewer" betroubaar genoeg om 'n "korrekte" vertolking van die wet te begelei, kwalik rekonstrueerbaar. Regsgeleerdes wat die cliché "bedoeling van die wetgewer" vrylik gebruik, sal tewens toegee dat dit eintlik maar húlle sinoniem vir "die veronderstelde betekenis van die wet" - en dus ' $n$ fiksie - is.

Common law Uitleg van Wette se klassieke manier om dié fiksie te oortroef fiksies is immers werklikheidsvreemd! - is om te sê dat die wetgewer sy bedoeling in die duidelike taal (clear language) van 'n wet uitdruk. Indien 'n wet in duidelike en ondubbelsinnige taal geskryf is en dus net een betekenis kan hê (waaroor almal sal saamstem), is daar geen twyfel wat die wetgewer bedoel het en wat die wet dus beteken nie. Taal kan 'n mens egter soms in die steek laat: die betekenis van 'n wet blyk nie altyd duidelik uit die woorde daarvan nie, of meer as een betekenis is taalkundig moontlik (vgl. weer eens Steyn, 1981:1-2). Dan is die common law-reëls en -vermoedens van wetsuitleg, met hulle voorskrifte oor hoe om onduidelikhede of meersinnighede op te klaar, die wetsuitlegger se volgende toeverlaat. Hierdie reěls en vermoedens veronderstel dat 'n ("redelike") wetgewer altyd op ' $n$ bepaalde manier redeneer en in die proses sekere standaardoorwegings verdiskonteer. Sê 'n wetsteks self dus nie in duidelike en ondubbelsinnige taal wat die wetgewer bedoel het nie, kan die reels en vermoedens van wetsuitleg, met hulle appèl op normale wetgewerslogika, aandui wat die wetgewer waarskynlik in gedagte gehad het.

Wat dus met die tipies Suid-Afrikaanse weergawe van die bedoelingsteorie gebeur, is dat die vertolkersfokus gladweg vanaf die bedoeling van die wetgewer na die taal van die wet verskuif. Die bedoelingsteorie word met ander woorde ' $n$ letterlike betekenis - oftewel letterknegtige teorie wat met 'n eerste oogopslag baie oortuigend lyk - en die grootste gros Suid-Afrikaanse regsgeleerdes inderdaad oortuig. D.V. Cowen (1976 en 1980) noem hierdie benadering tot wetsvertolking literalist-cum-intentionalist (letterknegtig-cum-intensionalisties) 
Bloot op gesigswaarde beoordeel, is dit nie duidelik of dit 'n geval van letterknegtige intensionalisme of intensionalistiese letterknegtigheid is nie. Cowen se tipering kan waarskynlık albei variasies op die tema akkommodeer (vgl. ook Du Plessis \& Corder, 1994:62) - maar dit is in elk geval nie deurslaggewend belangrik nie.

Die groot vraag is eerder of letterknegtig-cum-intensionalistiese wetsvertolking hoegenaamd aan die intense verwikkeldheid van 'n (juridiese) "verstaanswerklikheid" reg kan laat geskied. Ter wille van twee kort beoordelende tussenspele, word 'n oordeel hieroor voorlopig opgeskort. Die eerste tussenspel stel aannames oor die bedoeling van die wetgewer in so ' $n$ positiewe lig moontlik. Die tweede beoordeel dit optimaal negatief en diagnoseer daarna twee tekortkominge van letterknegtig-cum-intensionalistiese wetsuitleg wat as gevolg van die aanbreek van konstitusionalisme al hoe duideliker manifesteer. Eers ná die twee tussenspele word 'n balansstaat opgestel - weliswaar steeds voorlopig.

\subsection{Tussenspel 1: "Bedoeling van die wetgewer" in so 'n positiewe lig moontlik}

Wat is so verkeerd daarmee vir regsgeleerdes (of enigiemand) om hulle op fiksies soos "die bedoeling van die wetgewer" te verlaat? Is 'n fiksie nie maar 'n pons asinorum, 'n eselsbrug, na die verstaan van komplekse verskynsels nie? W.J. Witteveen (1988:401-445) is byvoorbeeld heel positief oor die rol van die fiksie as "geaccepteerde onwaarheid" in regsgeleerde vertolkingsdiskoers. In die alledaagse spraakgebruik sê ons dat die son opkom en ondergaan. Dit is 'n fiksie. Die aarde draai en vir 'n sekere gegewe tydsduur is 'n bepaalde deel van die aardbol in so 'n verhouding tot die son, dat die laasgenoemde se lig daaroor skyn. Hierdie verhouding verander so min of meer (afhangend van die tyd van die jaar) elke twaalf uur en dan word dit donker. Soveel detail maak dinge egter onnodig ingewikkeld. Daarom voel ons gemaklik met die fiksie dat die son (soggens) opkom en (saans) ondergaan.

Fiksie-logika veroorsaak dat regsgeleerdes die betekenis van 'n wetsteks aan die bedoeling van die wetgewer gelykstel - en daarmee tegelyk 'n besondere kenmerk van wetstekste uitdruk. As die kompleksiteit van wetgewingsprosesse en die komplekse samestelling van die meeste wetgewende liggame in ag geneem word, is daar nie 'n instansie van wie maklik gesê kan word dat dit (een van hart en sin en strewe) daadwerklik dit of dát "in gedagte" gehad het of presies sus of so wóú nie. 'n Mens kan dit kwalik van selfs 'n individuele wetgewer sê, byvoorbeeld van 'n minister wat regulasies (opgestel deur die staatsregsadviseurs) uitvaardig (tien teen een sonder om hulle te lees!). Maar wat maak dit saak? 'n Wet skryf voor dát (en hóédat) sekere dinge moet gebeur. Die betekenis van 'n wetsteks is dus onlosmaaklik vervleg met die veronderstelling dat die wetsouteur wil hê dat dié bepaalde wet - soos wetgewing oor die algemeen - 
(sekere) "dinge moet laat gebeur". Dié "outeur" is meesal 'n liggaam bestaande uit 'n verskeidenheid mense met verskillende sienings. Nogtans word van veral die juris (want hy/sy werk met wetsimplementering) vereis om die wet as produk van 'n effektiwiteitsintensie en dus van geldingsgerigtheid, ernstig te neem. Die fiksie van 'n wetgewersbedoeling kan hierdie vertolkersverantwoordelikheid honoreer sonder om noodwendig die betekeniskompleksiteit van die teks te ontken.

\subsection{Tussenspel 2: "Bedoeling van die wetgewer" so negatief moontlik verstaan}

"Die bedoeling van die wetgewer", ingeklee in "duidelike en ondubbelsinnige" wetstaal, kan ook beteken: "die duidelike bevel van 'n oppermagtige despoot wat sonder teëspraak gehoorsaam moet word". Vir die kritikus van brutale Zweck und Machtspositivismus (Wieacker, 1967:558) is dit die mees negatiewe betekenis waarin "bedoeling van die wetgewer" verstaan kan word. In sy toonaangewende intreerede wyt John Dugard (1971) die Suid-Afrikaanse regbank se oorwegende gedienstigheid aan die apartheidsbestel, aan wat hy elders (Dugard, 1978:xii) 'n "primitive positivist outlook" noem. Forsyth en Schiller (1981) kritiseer hom, met 'n mate van reg, omdat hy alle vorme van regspositivisme oor die kam van 'n outoritêre bevelsteorie skeer. Dugard (1981) se antwoord hierop is dat hy nie viool kan speel terwyl Rome brand nie: die Suid-Afrikaanse weergawe van regspositivisme wat hy kritiseer, is/was inderdaad brutale Zweck und Machtspositivismus

Wie van Dugard of Forsyth en Schiller toentertyd volkome gelyk had, maak tans nie soveel saak nie. Dugard se herkenning van 'n "primitive positivist outlook" in die tradisionele benadering tot wetsuitleg in Suid-Afrika is egter nie vergesog nie Die hoëpriester van regspositivisme in die common law-tradisie, John Austin $(1885: 86)$, beskryf 'n wet só

A law, in the most general and comprehensive acceptation in which the term, in its literal meaning, is employed, may be said to be a rule laid down for the guidance of an intelligent being by an intelligent being having power over him.

Hierdie beskrywing pas 'n letterknegtig-cum-intensionalistiese benadering tot wetsuitleg soos 'n handskoen. In Austin se skema is die soewerein die intelligente wese wat beveel. "Bedoeling van die wetgewer" beteken dus "die bevel van die koning". Bevelstaal is kenmerkend ondubbelsinnig en duidelik - dit is (inderdaad!) taal met 'n literal meaning. Om jou dus aan die duidelike en ondubbelsinnige taal van 'n wet te onderwerp, beteken om die (bevels-)wil van die soewerein, dit wil sê die wetgewer, te gehoorsaam.

Minder intens negatief, maar steeds óóp vir kritiek, is twee ander geykte aannames van letterknegtig-cum-intensionalistiese wetsinterpretasie. Soos ver- 
volgens aangetoon sal word, manifesteer hulle praktiese tekortkominge al duideliker as gevolg van die wetsteksvertolkingseise wat die epog van konstitusionalisme stel. Die eerste aanname wat onder skoot kom, stel die wetgewersbedoeling by wetsuitleg sentraal. Die tweede is die holruggeryde "duidelike en ondubbelsinnige taal"-tese wat in die geval van grondwetsvertolking, as gevolg van die aard van tipiese grondwetstaal, tot mislukking gedoem is.

\subsubsection{Die sentraliteit van die wetgewersbedoeling}

Artikel 35(2) van die oorgangsgrondwet (Grondwet van die Republiek van SuidAfrika, Wet 200 van 1993) het 'n bepaalde wetsvertolkingsprosedure gekonstitusionaliseer, naamlik grondwetskonforme vertolking (verfassungskonforme Auslegung) oftewel die reading down van 'n wetsteks vis-ä-vis die Grondwet. Hierdie leesstrategie word algemeen gebruik in regstelsels met 'n oppermagtige grondwet by die vertolking van gewone wette (vgl. oor die algemeen Betterman, 1986). Volgens artikel 35(3) was

... geen wet wat enige regte beperk ... grondwetlik ongeldig bloot uit hoofde van die feit dat die bewoording wat gebruik is prima facie die perke deur hierdie Hoofstuk [Fundamentele Regte] opgelê, oorskry nie, mits so 'n wet redelikerwys vatbaar is vir 'n meer beperkte uitleg wat nie sodanige perke oorskry nie, in watter geval die wet uitgelê word om 'n betekenis te hê in ooreenstemming met bedoelde meer beperkte uitleg.

Daar is nie meer 'n bepaling soos artikel 35(3) in die 1996-grondwet nie. Grondwetskonforme wetsvertolking bly nietemin 'n geldige, en trouens vereiste, manier van wetsvertolking wat voortvloei uit die eis tot regterlike selfbeheersing (judicial self-restraint) - sowel by wets- as grondwetsvertolking (Schuppert, 1988; Du Plessis, 1998:13). Hierdie leesstrategie het tot gevolg dat die sentrale vraag by wetsvertolking nie is wat die wetgewer "bedoel" het nie, maar watter van die moontlike betekenisse van 'n gewone wet met die Grondwet bestaanbaar is. Dit maak 'n groot verskil. In die verlede kon Suid-Afrikaanse howe - dikwels omdat hulle gedink het die taal van sekere wette is duidelik en ondubbelsinnig geredelik konkludeer dat die wetgewer wetsbetekenisse wat in stryd met ongeveer enige gangbare menseregtehandves sou wees, inderdaad "bedoel" het, en die howe het aan sulke betekenisse gevolg gegee. Deesdae moet howe sulke betekenisse, waar enigsins moontlik, behoedsaam vermy ten einde betwiste wetsbepalings optimaal téén ongeldigverklaring te vrywaar. Die bedoeling van die wetgewer soos tradisioneel verstaan, as dit enigsins as 'n gewer van wetsbetekenis sou kwalifiseer, kan dus hoogstens tweede viool speel.

Grondwetskonforme wetsvertolking doen egter nie afbreuk aan die bedoeling van die wetgewer as fiksie (soos in 3.2 hierbo verduidelik) nie - inteendeel. Die fiksie is ' $n$ manier om ' $n$ wet as produk van 'n geldings- (en, sou 'n mens kon byvoeg, 
geldigheids-) intensie ernstig te neem en só 'n bepaalde vertolkersverantwoordelikheid te honoreer. Regterlike selfbeheersing, die fons et origo van grondwetskonforme wetsvertolking, is 'n kenmerkende vergestalting van hierdie verantwoordelikheid.

\subsection{2 "Duidelike en ondubbelsinnige taal" in 'n grondwet}

Sedert die inwerkingtrede van Suid-Afrika se eerste oppermagtige grondwet op 27 April 1994, het dit tot Suid-Afrikaanse juriste begin deurdring dat die fundamenteelste van alle regstekste in die regstelsel, te wete die Grondwet, in alles behalwe duidelike taal geskryf is. Formulerings is opsetlik ruim en daarom dubbelsinnig: hulle kan altyd op meer as een manier verstaan word. 'n Grondwetsteks, juis omdat die Grondwet oppergesag het en duursaam is, móét oop en buigsaam wees en deur vertolking by veranderde tye en omstandighede aangepas kan word. Omdat gewone wette tradisioneel letterlik vertolk is, is hulle in baie detail opgestel. Deur baie woorde te gebruik, is probeer om vir soveel moontlik gevalle voorsiening te maak en soveel moontlik skuiwergate toe te stop - mede in die verwagting dat die wette "letterlik" uitgelê sal word. So word woordinflasie aangehelp. Die baie woorde van wette sê baie keer eintlik betreklik min en voorsien in elk geval nie elke gebeurlikheid nie.

Die epog van konstitusionalisme het 'n neiging laat posvat om meer en meer gewone wetgewing (en veral wette wat bedoel is om toonaangewend en duursaam te wees ${ }^{7}$ ) in die oop en buigsame styl van die Grondwet te skryf. Dit is óók die styl waarin geskrewe regsnorme in die Romeins-Germaanse regsfamilie geformuleer word (David \& Brierly, 1985:95-97). Regsreëls word algemeen en abstrak bewoord en wetstoepassers (soos die howe) word vertrou om hierdie algemene reels volgens hul eie goeie oordeel in besondere gevalle konkreet te maak en toe te pas. Waar wetstekste in hierdie styl opgestel word, sal 'n wetsvertolker wat volhou dat die betekenis van ' $n$ wet hoegenaamd uit die duidelike en ondubbelsinnige taal daarvan kan blyk, onvermydelik in die moeilikheid beland. Dit is toenemend in Suid-Afrika aan't gebeur.

\subsection{Die (steeds voorlopige) balansstaat}

Wat van letterknegtig-cum-intensionalistiese wetsvertolking weeg die swaarste: die bates of die laste? Dit is handig om die nogal verskillendsoortige insigte van twee ander outeurs hier by te haal, juis omdat nie een van hulle daarop ingestel is om finale waardebeoordelings na óf die bate- of die lastekant toe te maak nie. Al twee se analises is nietemin verhelderend want dit werp nuwe lig op sekere

7 Bv. die Wet op Arbeidsverhoudinge 66 van 1995 
Die sakelys vir wetsteksvertolking en dle epog van konstitusionallsme in Suid-Afrika

grondaannames en voorveronderstellings van letterknegtig-cum-intensionalistiese wetsvertolking.

\section{- Cross se historiese analise}

Rupert Cross (1995:10-20) vertel 'n stukkie common low-wetsurtleggeskiedenis wat veral publiekregsgeleerdes in Suid-Afrika waarskynlik sal verras. Dit is sedert ongeveer 1994 mode onder laasgenoemdes om hulle trou aan konstitusionalisme met kniebuigings voor doeldiende grondwets- en handvesvertolking (purposive interpretation) - allerweë as dié hermeneutiese vonds van die nuwe epog gereken - te bely (kyk bv. De Waal et al., 1999:125-127 se opsomming van die howe se houding). Doeldienende uitleg word as 'n onlangse ontwikkeling hooggeskat en as volstrekte voonuitgang op tradisionele letterknegtig-cumintensionalistiese uitleg voorgehou.

Die geskiedenis vertel volgens Cross egter 'n ander storie. In Engeland gaan doeldienende wetsteksuitleg die letterknegtig-cum-intensionalistiese benadering in tyd ongeveer twee eeue (of selfs langer) vooraf. Die common law se locus classicus vir doeldienende wetsuitleg, naamlik Heydon's case ((1584) $3 \mathrm{Co}$. Rep. 7a 7b), dateer uit die laat sestiende eeu. Regterlike regstelling en uitbouing van fragmentariese wetstekste was destyds onvermydelik want die parlement het ongereeld vergader. Doeldienende wetsuitleg was dus prakties genoodsaak. Dienstigheid aan die bedoeling van die wetgewer, en die daarmee gepaardgaande letterknegtigheid, was 'n veel latere uitwas van die Westminster parlementêre demokrasie en veral van parlementêre oppergesag (wat dit terloops nie verregaande maak om letterknegtig-cum-intensionalistiese wetsuitleg aan Austiniaanse regspositivisme te knoop nie).

\section{- Witteveen se retoriese analise}

Die "bevele" van die soewereine parlement vind hulle neerslag in wette wat mettertyd as outonome gesagstekste verselfstandig word. Witteveen (1988:14976) help 'n mens verstaan hoedat dit (kan) gebeur en watter implikasies dit het. Hy stel belang in die rol van die retoriek in die reg. Die retoriek het as direkte en interpersoonlike, mondelinge kommunikasiestrategie ontstaan. Met die opkoms van geskrewe en gedrukte tekste vind retoriese sturing al meer deur bemiddeling van tekste en dáárom indirek plaas. Omdat teksproduksie en -interpretasie onderskeie raak, ontwikkel die sturende skrifteks (anders as die gesproke woord) algaande tot 'n selfstandige entiteit en só word onder meer die outonome literêre teks en die regsteks as gesagsbron gebore. Die verselfstandigde skrifteks word gesien as 'n suiwer weergawe van die outeursbedoeling wat, so word verder geglo, deur "korrekte interpretasieprosedures" eenduidig vasgestel (sal) kan word. 'n Mens herken in hierdie (volgens Witteveen a-retoriese) kommunikasiemodel, wesenselemente van die letterknegtig-cum-intensionalistiese wetsuitlegstrategie. 
Die retoriese kommunikasiemodel vir sturende tekste wat Witteveen self aan die hand doen, gaan uit van 'n verdubbeling van die retoriese situasie wat aan teksproduksie en -interpretasie albei 'n eie regmatige plek gee. Die teksouteur "produseer" 'n teks gerig op "'n model-leser" wat hom- of haarself weer van die vertel- of uitdrukkingstrategie van ' $n$ implisiete teksouteur rekenskap probeer gee. Sowel leser as outeur benut konvensies wat deur die interpretasiegemeenskap erken en gehanteer word. Ongelukkig ontbreek die ruimte om Witteveen (1988: 219-262) se toepassing van dié model op wetsteksvertolking volledig uiteen te sit. Kortweg gesê, is die waarde van sy insigte dat dit die veronderstelde selfstandigheid van wetstekste as eenduidige betekenisdraers ondermyn of, ten minste, relativeer. ${ }^{8}$

Daar is, soos mettertyd sal blyk ("filosofies gesproke"), ander maniere om tot soortgelyke insigte te kom. Witteveen verkies om die pad van retoriese analise te loop - en dit is betekenisvol. Regsgeleerdes kan tereg skepties wees oor die manipulasiepotensiaal van die retoriek as "gevaarlike kuns" (Witteveen, 1988: 111-148) - veral by wetsvertolking. Die willekeurige kies van 'n bepaalde vertolkingsresultaat kan retories-behendig (en -manipulatief) geregverdig word óók tot voordeel van 'n maghebber wat 'n vooropgesette voorkeur vir 'n bepaalde resultaat alte geredelik as "'n goeie regsargument" kan probeer vermom (Müller, 1997:123-124 en 370-371).

Witteveen (1988:7-9) maak egter 'n onderskeid tussen "retoriek" ("practical rhetoric") en retorika ("reflective rhetoric") wat vir wets- en, breër gesproke, regsvertolking ter sake is. Laasgenoemde lê ook 'n grondslag om vertolkerswillekeur te temper. Retoriek is die verskynsel dat 'n spreker bepaalde tegnieke gebruik (of misbruik) om "'n breër publiek" van dít of dát te oortuig. Retorika is 'n corpus insigte oor praktiese retoriek wat vir deelnemers aan verskillende genres vertolkingsredenasies, soos wets- en regsvertolking, die geborgenheid van 'n interpretasiekader bied. Dié betrokke kader suggereer nie (dié) "korrekte antwoorde" op bepaalde vertolkingsvrae nie. Dit rugsteun egter die geloofwaardigheid en veral legitimiteit (-in-konteks) van sekere antwoorde - enkeles uit vele moontlikhede! - waarby op bepaalde ("aanvaarde") maniere uitgekom is.

Oor die waarde van retoriese insigte vir wetsteksvertolking spesifiek in ons situasie, sal in die slotparagraaf ( 5 hieronder) die een en ander opgemerk word. van oordeel dat fasette van my eie benadering tot wetsteksvertolking, en veral bepaalde vertolkingstrategieë wat ek aan die hand doen, juis die nosie van 'n selfstandige wetsteks as outonome (of dan ten minste eenduidige) betekenisdraer veronderstel. Diè kritiek is gegrond en in die verdere ontwikkeling van my eie idees neem ek dit emstig. 


\section{4. "'n Meer moderne hermeneutiese siening"}

In Suid-Afrika is dit feitlik uitsluitlik regsakademici wat hulle koppe oor die transformasie van ons regs- en veral wetstekshermeneutiek breek. Diesulkes soek maniere om wat N.J.C. van den Bergh (1982:680) 'n "meer moderne hermeneutiese siening"9 noem, integrerend déél van regsteksvertolking te maak. Sulke pogings is nie onomstrede nie. Hulle is, om mee te begin, intens filosofies en vir "gewone" juriste dus, soos Devenish (1992:52) dit so mooi van my eie vorige pogings sê, "abstruse and not easily comprehensible and ... unlikely to find ready acceptance". Du Toit (1998:43) het gelyk dat "méér" eerder as "minder" filosofie - skynbaar van die regte (en dikwels dus inderdaad die "abstruse") soort - SuidAfrikaanse regsgeleerdes kan help om van die klemme en voetangels van oorgelewerde vooroordele los te kom. Onvermydelik ondermyn dit oorgelewerde sekerhede - en akkumuleer so die omstredenheid wat uit die staanspoor reeds aanwesig was. Suid-Afrikaanse juriste kan doen met 'n ondermyning van veral sekere van hulle sekerhede - hopelik dié wat betekenisloos leeg en beslis dié wat positief skadelik is. Hieroor later meer.

Daar is nietemin sekerhede waarvan juriste nie kán loskom nie, byvoorbeeld dat wetsteksvertolking die konkretisering van 'n verordende regsteks behels (Muller, 1997:186-208) en dus die verantwoordelikheid om dié teks as lewensvatbare oplossing vir 'n probleemsituasie te "laat probeer werk". Daar is yuppıe-radikale wat dit kan bekostig om, onaangeraak deur hierdie verantwoordelikheid, onder die vaandels van hulle with it-gunstelingfilosofieë (hoe byderwetser hoe beter!) voort te marsjeer en kritikasterig te deklameer dat enige beredeneerde betekeniskeuse (komend van veral regseksperte) altyd vermomde onreg is. Hierdie kritikasters dink dat hulle taak as "denkers" afgehandel is sodra die snippers van hul skalpelskerp analises netjies bymekaar geskraap en veilig in omgewingsvriendelike vullishouers van politieke korrektheid weggegooi is. Die tipiese geldingsgerigtheid van wetstekste verplig egter die juris wat dit ems met geregtigheid probeer maak (en daar is sulke ernstige juriste) om sulke snippers weer te probeer aanmekaarplak, wetend dat die "herstelde" eindproduk meer of minder maar onvermydelik krom en skeef gaan wees (vgl. ook Du Toit, 1998:5152).

Kreatief-idealistiese transformeerders (en hulle is nie almal yuppıe-radikale nie!) en klassiek-tradisionele (maar ernstige) juriste in Suid-Afrika, het ongelukkig tot nog toe by mekaar bly verbypraat - óok oor wat die epog van konstitusionalisme vir die transformasie van wetsteksvertolking in 'n markant "anderster situasie" verder aan in hierdie artikel ontwikkel word, filosofies gesproke, postmodem eerder as modern is. "Modern" moet dus meer as "kontemporêr", "tydgenootlik" of "hedendaags" verstaan word 
(sou kon) beteken. Gegewe hierdie kommunikasiegaping, en gestel daar is uit al twee die groeperings hierbo diegene wat 'n "meer moderne hermeneutiese siening" (of sienings) vir 'n vernuwende wetstekshermeneutiek wil benut (die vernuwers), wat is dan op die agenda? Dalk 'n filosofie? Iemand se filosofie? 'n Goeie begin is om vir albei hierdie moontlikhede nadruklik "nee" te sê - en só die verwagting van óf 'n alles insluitende metanarratief óf 'n gunstelingfilosofie die bodem in te slaan. Iets meer oor hierdie dubbele nee.

- Geen enkele filosofie kan 'n sisteem genereer met aanwysings oor hoe om wetsvertolkingsprobleme (met hulle bypassende oplossings) ewe netjies te hokkie en te vakkie nie. Dié insig behoort al die vernuwers te pas:

- die transformeerders wat in 'n tipies postmodernistiese denktrant, grand narratives loën (Cilliers, 1998:113-114);

- die meer klassiek-tradisioneles wat nie kans sien om hulself aan die verwikkeldhede van filosofiese sisteme te verkoop nie - dít is waarskynlik die bedenking wat Devenish met sy skeptisisme oor die "abstruseness" van my eie vorige poging probeer verwoord.

Filosofie(ë) onderliggend aan "meer moderne hermeneutiese sienings" kan vir vernuwers hoogstens 'n knipseldiens vir die plakboek van 'n getransformeerde regs- en wetshermeneutiek bied. In 'n verwikkelde en gefragmenteerde leefwerklikheid is so 'n eklektisisme (want dit is wat dit is) nie intellektueel onbehoorlik nie. Dit is egter ook nie 'n vrypas tot "everything goes" nie (Cilliers, 1998:115-116). Die eise van die konkrete-situasie-in-konteks "reguleer" elke knipselkeuse met 'n toespeling op die eventuele verwerkliking van wat (met huiwering en tot tyd en wyl) "geregtigheid" kan heet.

Ook vanuit 'n ander gesigshoek bekyk, is knipselkeuses nie willekeurig nie $\mathrm{Na}$ die insig van die wysgerige hermeneutiek a la Gadamer, ontgin teksvertolking betekenismoontlikhede in 'n hermeneutiese sirkelaksie tussen leser, teks en tradisie, maar is dit terselfdertyd onderhewig aan die beperkings wat dié hermeneutiese sirkel oplê (kyk 4.5 hieronder). Vertolkingstrategiese nadenke, met 'n beroep op filosofiese insigte, is deel van dié proses met sowel sy moontlikhede as beperkings. Die nadenkende teksleser besluit gevolglik nie sommer na willekeur op hiérdie of dáárdie filosofiese knipsel nie. Teks en tradisie beperk leserskeuse(s)

- Net soos geen metanarratief alle wetsvertolkingskwessies "netjies" en sistematies kan beredder nie, net so is daar ook geen kontemporêre Paulusse of Apollosse - hoe aantreklik hulle insigte ook al - wat regshermeneutiese alleen- of selfs voorkeurseggenskap geniet nie. 'n Vernuwingsproses wat dit met "meer moderne hermeneutiese sienings" erns het, is nie 'n filosofiese 
Die sakelys vir wetsteksvertolking en die epog van konstitustonalin. In Suid-Afrika

modeparade met wenners en verloorders nie. Alle kontemporêre genereerders van lees- en verstaanstrategieë staan in 'n ry van knipsel-outeurs - sommige verder vorentoe en ander verder agtertoe. Hulle knipsels word, tipies in die trant van "meer moderne hermeneutiese sienings", na die eise van konteks en konkrete situasie geëvalueer.

Sekere knipselkeusemoontlikhede word vervolgens kortliks en voorlopig verken. Enkele eietydse, hermeneutiese insigte - of rubrieke, sou 'n mens ook kon sê wat reeds met vrug by regsgeleerde diskoerse betrek is, word bygehaal. Die meeste van hierdie insigte ondermyn in 'n mindere of meerdere mate sowel die leë as die skadelike sekerhede van tradisionele, regsgeleerde wetsteksvertolkers Al kom die verskillende rubrieke een-een en na mekaar aan die beurt, is hulle in werklikheıd in mekaar vasgewikkel en moet die een in die lig van die ander verstaan word. Nodeloos om te sê, sowel die lys van insigte en die verkenning wat volg, maak nie naastenby aanspraak op volledigheid nie. Daar word inderdaad net na die hoof- en subopskrifte van sekere knipsels gekyk.

\subsection{Rubriek 1: 'n Kritiese magsbewussyn}

Die insig: 'n Standaardvertolking van regstekste wat veronderstel

- dat hulle selfstandige gesagsdraers is en

- dat hulle op geykte betekenisse van regskonsepte gebaseer is,

maskeer dominante klasse/groeperinge/kategorieë in die samelewing se bestendiging van hulle hegemonie, met 'n ongegronde beroep op die neutraliteit en onpartydigheid van die reg.

Grondliggend aan hierdie insig is die tese dat gevestigde kennis (en daarom ook verstaansmodi) intiem met 'n (Nietzschiaans gesê) "wil tot mag" en dominasie vervleg is, en trouens hulle stukrag daaruit put: kennis is inderdaad mag ... en mag is kennis. Michel Foucault is waarskynlik die bekendste kontemporêre eksponent van hierdie tese (Hunt \& Wickham, 1994:12-14). Hy gee met sy kritiese analise van die juridies-diskursiewe ("juridico discursive") konsepsie van mag, uitdrukking daaraan in regsverband (Foucault, 1990:82-83). Magsuitoefening word, volgens hom, in regsterme ingeklee en die reg word voorgehou as 'n "neutrale" vergestalting van konsepte soos geregtigheid, regte en vryhede of van (regs-)figure soos kontrakte (Foucault, 1990:87). Die reg is boonop kontradiktories-tweeduidig: dit maak gewag van individuele vryheid, maar legitimeer tegelyk die uitoefening van staatsmag (Litowitz, 1995:13).

Die kontemporêre kennis-is-mag-tese is ook vanuit ander gesigshoeke (verder) ontwikkel, dit word met varërende intensiteit verkondig en die verskynsel wat daardeur aan die lig gebring word, word met verskillende grade van radikaliteit "bestry". In Critical Legal Studies-jargon heet die verskynsel self byvoorbeeld 
"illegitieme hiërargieë" ("illegitimate hierarchies"), wat blootgelê word deur trashing (dit wil sê die afpluk van die regsmaskers waaragter 'n samelewing onreg en uitbuiting probeer wegsteek). Dié hiërargieë moet met woord en daad bestry word, die uitgesproke oogmerk synde om van hulle ontslae te raak (Russell, 1986:14-16, 19)

Miskien minder polities-aktivisties, maar nie daarom minder intens en radikaal nie, is dekonstruksie ${ }^{10}$ a la Jacques Derrida se inversie van hiërargieë:

[I]n a classical philosophical opposition we are not dealing with a peaceful coexistence of a vis-á-vis, but rather with a violent hierarchy. One of the two terms governs the other (axiologically, logically, etc.), or has the upper hand. To deconstruct the opposition, first of all, is to overturn the hierarchy at a given moment (Derrida, 1981:41).

Dekonstruksie aldus beskryf, speel op die vlak van konsepte en idees af en rammei nie (soos trashing in die geval van Critical Legal Studies) die onregverdige strukture in die samelewing ooglopend en direk nie. Dat dekonstruksie as projek egter ook 'n daadwerklike regstoepassing het, het enkele Suid-Afrikaanse regsakademici reeds met interessante effek geillustreer (vgl. bv. De Ville, 1997 en Van der Walt, 1998). 11

Volgens Derrida (1992:14-15) is die reg dekonstrueerbaar (omdat dit in die eerste plek gekonstrueer is) en dit is nie slegte nuus nie: dekonstruksie van die reg kan dit gedurig vernuwe (Caputo, 1997:130). Dekonstruksie van die reg is egter nie tegelyk 'n dekonstruksie van geregtigheid nie

Justice in itself, if such thing exists, outside or beyond law, is not deconstructable. No more than deconstruction itself, if such a thing exists. Deconstruction is justice (Derrida, 1992:15).

Dekonstruksie het besondere potensiaal om konvensionele vertolkings van regstekste te bevraagteken én sodoende besinning oor nuwe vertolkingstrategieë op dreef te help bring. Dit help regsgeleerdes insien hoedat ("suiwer") regsdogmatiese beredeneringe deurdring word van juis dié ideologiese denke wat hulle probeer maskeer (Balkin, 1987:744). Soos verder aan sal blyk, breek 'n omkeer van regshiërargieë ook vars insigte oor die rol van taal en konteks in wetsteksvertolking oop - sonder om voor te gee dat dit (gesaghebbend) alternatiewe vertolkingskanons (canons of construction) óf postuleer óf sanksioneer.

10 Iets anders as Critical Legal Studies se trashing

11 Vir ander nie-Suid-Afrikaanse voorbcelde, kyk Balkin (1987 en 1994) en Rosenfeld (1992). Kyk ook Fcldman (1996) 
Die vars insigte van dekonstruksie, deursypel "meer moderne hermeneutiese sienings" inderdaad in velerlei opsigte.

Dekonstruksie het egter beperkings. Dit is 'n intellektueel gesofistikeerde denkmodus, kwesbaar vir misbruik as modefilosofie, en daarom potensieel 'n speletjie vir yuppie-radikalistiese buitestanders. Dekonstruksie van die reg en regstekste lei tot die ootmoedige besef dat geregtigheid, as nie-dekonstrueerbare, onhaalbaar is. Die geldingsgerigtheid van die wetsteks noop die wetsteksvertolker geregtigheidshalwe egter tot keuses - tot skadebeperking deur die onvermydelike rekonstruksie van hiërargieë - en hiermee kan dekonstruksie nie juis help nie (Du Toit, 1998:50).

\subsection{Rubriek 2: Die deurslaggewende belang van taal vir betekenis}

Die insig: Uit taal, deur taal en binne taal as komplekse sisteem, is alle betekenis.

Bogenoemde stelling is sterker gestel as om te sê dat danksy taal daar betekenis is. Laasgenoemde kan ook beteken dat taal betekenismedium is. Dít is 'n instrumentalistiese siening van taal wat ekself (ten onregte) lank gehuldig het en waarvoor De Ville (1999) my tereg kritiseer. Dié eng siening postuleer 'n verselfstandige (regs-)teks as betekenisdraer met taal as medium wat toegang tot 'n outonome teksbetekenis gee. Sowel De Ville (1998) as Cilliers (1998:37-47) maak dit egter duidelik dat taal-as-komplekse-sisteem só geëmaskuleer word. Cilliers se verhelderende uiteensetting van die Derrida-Saussure-debat lê hier 'n insiggewende verband met dekonstruksie se ontkenning van die onderskeid tussen ('n) betekenaar (signifier) en die betekende (signified). Saussure probeer die tradisionele aanname dat taaltekens (betekenaars) metafisies-aanwesige ietse (betekendes) "van betekenis voorsien", vernuwe. Hieroor is Derrida skepties: hy kan nie met 'n metaphysics of presence (en dus 'n "dáárheid" van betekendes) saamleef nie. Betekendes bestaan nie - is nie teenwoordig nie. Betekenis veronderstel eerder 'n komplekse heen-en-weer-spel, 'n aksie en reaksie van niekonstante, nie-durende en nie-metafisies teenwoordige betekenaars waarin spore (traces) van mekaar oor en weer voorkom. Die een beteken die ander, maar slegs onvolledig en voorlopig. Betekenis is nooit, op 'n gegewe tydstip, vasstaande dáár nie. Die talige rondspeel van betekenaars konstitueer dit weer en weer en verlê en verplaas dit ewe frekwent. Betekenismoontlikhede is oonoorsigtelik. Taal is die hiperkomplekse sisteem wat so 'n betekenisproliferasie onafwendbaar maak. Daarom en daartoe lê taal onbegrens óóp. Betekenis word gerelativeer, taal as betekenisgenereerder (maar dan ook net in dié hoedanigheid) daarenteen nie Maar let wel: betekenis is óóp en nie arbitrêr nie. Taal as betekenisgenereerder is hiperkompleks ja, maar dit is steeds 'n sisteem. 
As taal ' $n$ allesdeursurende voortbringer van betekenis is, moet 'n mens natuurlik die moontlikheid ernstig oorweeg dat die duidelike en ondubbelsinnige taal van 'n wetsteks - as so iets moontlik is, soos Derrida sou sê - letterknegtig-cumintensionalisties gesproke "die régte betekenis van die teks" onbetwis tot uitdrukking kan bring. Ekself het voorheen dié logika probeer oortroef deur taal as rolspeler in die betekenisdrama tot betekenismedium te relegeer (Du Plessis, 1986:50; Du Plessis \& Corder, 1994:66). Dit was nie nodig nie - selfs al sou dit geregverdig wees (wat dit nie was nie). Taal as alomteenwoordige genereerder van betekenis het geen hiërargiese méérwaarde oral waar betekenis ontstaan nie, maar is eerder 'n alomteenwoordige "dienaar" van die vermenigvuldiging van moontlike betekenisse. Letterknegtig-cum-intensionalistiese "duidelike en ondubbelsinnige taal" is a priori ingehokte taal. Dit is nie meer taal in radikale sin nie maar bloot 'n essensialistiese en daarom geëmaskuleerde betekenisgewer - 'n medium in diens van die (slegs) één betekenis van 'n vermeend outonome wetsteks

Common law-wetsuitleg se tradisionele aanname dat woorde 'n gewone betekenis kan hê, staan ook onder verdenking. Geen betekenaar is op sigself betekenisvol nie, maar is dit slegs in interaksie met ander labiele betekenaars. Woorde gee met ander woorde aan mekaar betekenis. Selfs taal het nie ("besit" nie) so 'n "gewone betekenis" nie. Die heen-en-weer-spel tussen betekenaars bring betekenis voort en dít maak taal "betekenisvol". Taal as komplekse sisteem maak op haar beurt weer betekenis vir individuele betekenaars moontlik (Cilliers, 1998:44-46).

Juis die alomteenwoordigheid van taal dáár waar betekenis is, maak dat taal-inaksie aan die unieke tekswees van 'n teks gestalte gee. Genretaal het bestaansreg (kyk ook punt 2 hierbo) maar geen genretaal - óók wetstaal - is kenmerkend duidelik en ondubbelsinnig nie

Die kanons van wetsteksvertolking is nie reels wat 'n mens help om die "regte betekenis" van wette te ontdek nie. Hulle is egter regverdigingsgronde vir die beperking van wetsteksbetekenisse - wat 'n móét is, want sonder die maak van regverdigbare keuses kan die kenmerkende geldingsgerigtheid van wette nie gehonoreer word nie.

\subsection{Rubriek 3: Verreikende konteksgevoeligheid}

Die insig: Betekenis kan alleen betekenis-in-konteks wees. Nie net die struktuurelemente van, of die "ander gedeeltes" in 'n wetsteks bepaal die betekenis van 'n spesifieke wetsbepaling onder oorweging nie maar die geheel van die regs- en sosiale "omgewing" waarin die teks in 'n heen-en-weer-spel met ander tekste gewikkel is. 
Hierdie insig bring 'n mens weer, langs 'n filosofiese pad, by die onttroning van die selfstandige teks waarna in 3.5 hierbo vanuit 'n retoriese gesigshoek gekyk is.

'n Teks is nie 'n entiteit opgebou uit taal as 'n bestanddeel nie - al is taal ook die hartklop en lewensbloed daarvan. In 4.3 hierbo is verduidelik dat betekenis slegs in die heen-en-weer-spel tussen betekenaars moontlik is. Dit impliseer 'n verweefdheid van betekenaars waarvan spoorelemente (traces) oor en weer in mekaar voorkom. "This interweaving," sê Derrida (1981:26), "results in each 'element' - phoneme or graphene - being constituted on the basis of the traces within it of other elements of the chain or system. This interweaving, this textile, is the text produced only in the transformation of another text".

'n Teks is, met ander woorde, net soos elke individuele taalelement wat dit beteken, self ' $n$ betekenaar in interaksie met ander soortgelyke betekenaars - 'n geskrif wat na ander geskrifte heenwys (Rosenfeld, 1992:153). Dit het verskeie implikasies vir wetsteksvertolking waarvan slegs enkeles hier kortliks te berde gebring word

Sedert appèlregter Schreiner se minderheiduitspraak in Jaga v. Doonges (1950 (4) S.A. 653 (A)) is sporadies in ons regspraak aanvaar ${ }^{12}$ dat konteks die betekenis van 'n wet medebepaal. Hierdie insig was 'n goeie begin om wetstekste betekenisgewend na hulle konteks toe oop te stel, maar het steeds berus op die konvensionele aanname dat die konteks lig op 'n in die wetsteks reeds aanwesige betekenis werp. Of 'n mens dus met die duidelike en ondubbelsinnige taal van 'n wet begin en na die konteks toe uit lees of, so nie, taal en konteks van die begin af saamlees, sal volgens die hof nie juis 'n verskil maak aan die vertolkingsresultaat nie (kyk ook Du Plessis, 1986:107-108). Dat buite die intens gekompliseerde wetstekskonteks wetsteksbetekenis hoegenaamd nie moontlik is nie, oorweeg die regter nie eens nie, want vir hom lê die betekenis van die wet uiteindelik en slegs in die wetsteks.

Wetsteksvertolking is meesal die ontginning van die moontlike betekenisse van 'n spesifieke wetsbepaling (provision) wat in 'n omvattender wetsteks soos 'n statuut, 'n grondwet, 'n stel reels of regulasies, ensovoorts voorkom. Sistematiese interpretasie is 'n erkende wetsteksvertolkingsprosedure waarvolgens vereis word dat die individuele bepaling in die konteks van die geheel van die wetsteks (die intratekstuele konteks) verstaan moet word (Du Plessis, 1998:14-15). Die oopheid van die teks "na buite" maak dit egter onafwendbaar dat 'n wetsbepaling ook in die lig van 'n ekstratekstuele konteks gelees moet word: alles in die

12 In die laat-tagtiger-, vroee negentigerjare was dit selfs mode om hierdie "verligte" minderheıdsuitspraak ter ondersteuning van meer progressıewe wetsınterpretasies aan te haal. 
"teksomgewing" waaraan talig uitdrukking gegee kan word (en wat self ook tekste is), is medebetekenaars van 'n wetsbepaling. Dit is 'n mondvol gesê. Juriste begin wetsteksinterpretasie gewoonlik met verwysing na voor die hand liggende, medebetekenende tekste van 'n regsaard: regsgeleerde vertolkingskanons, ander wette, gewysdes, historiese regsgeskrifte, tydgenootlike regsgeskrifte ensovoorts. Daar is egter ook tallose ander tekste in die sisteem wat nie as tipies juridies beskou word nie, maar wat 'n wetsbepaling (kan) medebeteken: historiese tekste, sosiale tekste, godsdienstekste, selfs literêre tekste - om maar net enkeles kategoriegewys te noem. Ook hier staan die wetsteksvertolker voor die eis om uit die haas grensloos-onoorsigtelike aantal medebepalers van die wetsteksbetekenis, dié te kies wat (waarskynlik) op 'n eventuele verwerkliking van geregtigheid sal toespeel.

Die oopheid van 'n wetsteks nooi vertolkers, anders as slegs regseksperte, tot medevertolking uit. Dit is veral waar van 'n teks soos die Grondwet - die oopste en "mees publieke" van alle wetstekste. Volgens Peter Häberle (1978:155-181) is 'n grondwet 'n "publieke proses" (offentlicher Prozeß) aan die vertolking waarvan 'n offene Gesellschafi meedoen. Offen beteken "oop" sowel as "publiek" en dui onder meer op die ruimte vir grondwetskonkretisering in die burgerlike samelewing (civil society) (Du Plessis, 1996:215). Oor vertolkingsvraagstukke wat voor die hof kom, moet natuurlik regterlik uitsluitsel gegee word. Dit beteken egter nie dat slegs die howe, met die Konstitusionele Hof aan die spits, kompetente of selfs gesaghebbende vertolkers van die grondwetsteks is nie. Al beëindig regterlike uitsluitsel 'n bepaalde proses (tot tyd en wyl), handel dit nooit die vertolking van die teks af nie (selfs nie eens al is dit net 'n enkele wetsbepaling nie). Dit is die nie-regterlike vertolkers van die Grondwet wat dit die meeste van die tyd in konkrete lewensituasies, van dag tot dag, vertolk. Slegs 'n baie klein persentasie van alle grondwetsvertolkingsvrae beland ooit in die hof? Dit is ook die nie-regterlike vertolkers se verstaan van die Grondwet (al is dit soms met regskundige hulp) wat hofprosesse vir die regterlike bereddering van vertolkingskwessies inisieer en op hierdie wyse effektief déél is van 'n daadwerklik gevolgryke vertolkingsprojek.

Ekspertvertolkings van wetstekste en van die Grondwet is nie "beter" of meerderwaardige vertolkings nie. Die kundige is nie 'n waarsêer wat gesaghebbend kan sê wat eintlik "in die teks staan nie". Daar "staan" in elk geval nie "betekenis" in 'n wetsteks nie. Nogtans sal ek met Du Toit (1998:46-47) swaarde wou kruis indien haar gegronde sinisme oor "ekspertbetekenis" impliseer dat die kundige lees van 'n wetsteks in prinsiep geen eie waarde, anders as enige ander lesing, het nie. Kundige lesings van genretekste soos literêre tekste, filosofiese tekste, godsdienstekste en dan ook regstekste is tog nie ongewoon (of ongevraagd) nie. Die ekspert het gewoonlik ervaring van verskillende leesstrategieë gangbaar in die vakgebied, van tegnieke wat teksouteurs gebruik om tekste te produseer en 
van die vaktradisie wat as't ware in die teks ingeskryf staan. Kundigheid kan natuurlik ook ooglede wees waarteen die ekspertvertolker vaskyk en so die "werklike werklikheid" miskyk. 'n Eksperttekslesing, gerugsteun deur gedeë en ondersoekende vakkundigheid, kan egter ook daarna streef om dié lesing te wees

- wat 'n "slegs een betekenis"-tese (en verdigsels oor inherente teksbetekenis) die bodem inslaan;

- wat die betekenisrykheid van die teks honoreer (juis deur verskillende betekenismoontlikhede oop te laat),

- en wat deur gedurige nadenke oor vertolkingskwessies as sodanig, maar ook ter wille van die besondere teksgenre, onafgehandelde items op die vertolkingsagenda van die vakgebied (en van die oop gemeenskap van vertolkers) plaas.

\subsection{Rubriek 4: Vóórverstaan}

Die insig: Ons vóórverstaan begelei ons verstaan en maak dit trouens moontlik. Hoe dieper weggesteek ' $n$ vóórverstaansaanname, hoe intenser en verreikender die effek daarvan op ons verstaan.

Dat hierdie insig eintlik 'n verstaansóópheid waarmerk, sien Hans-Georg Gadamer (1976:9) treffend raak:

[i]t is not so much our judgments as it is our prejudices that constitute our being ... [T] he historicity of our existence entails that prejudices, in the literal sense of the word, constitute the initial directedness of our whole ability to experience. Prejudices are biases of our openness to the world. They are ... conditions whereby ... what we encounter says something to us.

Vooroordeel is nie per definisie bigotterie nie. 'n Vooroordeel hoef nie vals, skeefgetrek of ongefundeer te wees nie, maar kan ook as 'n goed gefundeerde, voorlopige of "voorloper"-beoordeling verstaan word. As sodanig is 'n vooroordeel ' $n$ bemiddelaar tussen bestaande en nuwe kennis wat ' $n$ mens help om die onbekende op sterkte van die bekende te verstaan (Gadamer, 1975:256-269). "Vooroordele" só verstaan, is gesaghebbende vooraf-oordele (pre-judgements) wat die verstaan van 'n teks bemiddel; hulle manifesteer nie 'n willekeurige, oorhaastige (ubereilte) vooringenomenheid nie.

Hoe hanteer die juris as vertolker vooroordele en vóórverstaan (sy/haar eie en dié van ander) in regsvertolking en spesifiek wetsteksvertolking? Daarvoor is daar nie ' $n$ resep nie. Die beste raad is om nie te probeer voorgee dat ' $n$ mens hulle kan oorstyg of, erger, dat jy hulle nie het nie. Dit is 'n goeie begin om soos waamemende regter Kentridge in S. v. Zuma and others (1995(4) B.C.L.R. 401 (S.A.) par. 17), die eerste gerapporteerde uitspraak van die Konstitusionele Hof, 
te erken dat dit nie maklik is nie "to avoid the influence of one's personal intellectual and moral preconceptions" "one" synde die regter self). Stanley Fish (1989:358) gee 'n raak beskrywing van wat gebeur indien die regshermeneut vóórverstaan agter (byvoorbeeld) duidelike en ondubbelsinnige taal probeer wegsteek:

Meanings only become perspicuous against a background of interpretive presumptions in the absence of which reading and understanding would be impossible. A meaning that seems to leap off the page, propelled by its own self-sufficiency, is a meaning that flows from interpretive assumptions so deeply embedded that they have become invisible.

'n Té beskeie erkenning van presies hoe verreikend individuele vooroordele wetsteksinterpretasie beinvloed, sal nie deug nie, want soos Du Toit (1998:48) verduidelik

[I]f hermeneutics in the twentieth century has taught us anything at all, then it is that our own biases are invisible to us, and can only become visible through an encounter with texts of all kinds that alienate us from ourselves. Ricoeur talks of appropriation through alienation - there is simply no other route.

Dít maak dat vóórverstaan een van die baie moeilik hanteerbare punte op die agenda van wetsteksvertolking is. 'n Terloopse "toegewing" soos dié van waarnemende regter Kentridge in die Zuma-saak (al klaar heel ongewoon vir 'n SuidAfrikaanse regter) help nogal, maar gaan nie ver genoeg nie. Regsakademici het 'n belangrike rol te speel om die vervreemdingsproses waarna Du Toit verwys, by veral regters, aan te help. 'n Mens dink hier weer aan die verdienstelike werk van Donald Nicolson (1992), pas voor die aanbreek van die epog van konstitusionalisme, waarin hy die effek van ideologie as Weltanschauung op die uitsprake van regters onder die "ou bedeling" aan nugter, grondige en insiggewende analise onderwerp het. Baie van wat Nicolson toe gesê het, bly in die nuwe bedeling toepaslik. Aanpassings is egter nodig want die epog van konstitusionalisme maak die regspraak 'n operasionele gebied óók vir voorheen gediskrediteerde ideologieë

\subsection{Rubriek 5: Die twee-eenheid van verstaan en toepassing}

Die insig: Die (moontlike) toepassings van ' $n$ wetsteksbepaling begelei altyd die vertolking daarvan. ' $n$ Mens kan nooit 'n wetsbepaling los of afgesien van die toepassingsmoontlikhede daarvan verstaan nie. ${ }^{13}$

13 Gadamer (1975:308) stel dit soos volg: "Der Jurist faßt den Sinn des Gesetzes von dem gegebenen Fall her und um dieses gegebenen Falles wille" 
'n Wetsteks is baie soos 'n musiekstuk. 'n Mens verstaan dit nie heeltemal deur dit net te lees nie. Jy moet ook 'n "uitvoering" daarvan beleef. Die volle uitwerking van byvoorbeeld wetgewing word nie duidelik bloot uit dit wat op papier in wetboeke geskryf staan nie, maar eerder uit die manier waarop wette vertolk en dan in die praktyk toegepas word. Iemand wat musiek goed kan lees, kan ook die musiek "hoor" wanneer sy of hy 'n musiekstuk lees. 'n Wetsteksvertolker, veral een met ervaring, lees ' $n$ wetsteks soortgelyk. Jy stel jou as't voor hoedat 'n wetsbepaling in 'n konkrete lewensituasie gaan "klink". Dit kan wees omdat jy op 'n gegewe moment 'n oplossing vir 'n spesifieke probleem soek. Dit kan ook wees omdat jy 'n probleem bedink oftewel hipotetiseer.

'n Wetsteks is altyd betekenismatig óóp ook vir, voor en teenoor die konkrete situasie wat dit trag te beredder. 'n Teksbetekenis vir of werklike óf gehipotetiseerde probleemoplossings word nie slegs deur die wetsteks self gegenereer nie, maar onvermydelik óók deur die eise van die situasie. Hierdie twee-eenheid van wat tradisioneel "uitleg" en "toepassing" heet, maak dat Müller (1997:186208) wat grondwetsvertolking betref, Konkretisierung (konkretisering) bo Auslegung (uitleg) as die mees beskrywende term vir die proses verkies. Daarmee (asook in die uitwerk van sy konkretiseringsmodel) beklemtoon hy dat die wetsteks qua normprogram sowel as die probleemsituasie qua feiteprogram, deurslaggewend op die uitkoms van grondwetsvertolking inspeel.

Die twee-eenheid van interpretasie en toepassing is ook die slotsom van HansGeorg Gadamer se wysgerige hermeneutiek wat historiese teksbetekenis in die hede situeer (Bönninghaus, 1998:51-58).14 Betekenis word in die onderlinge interaksie tussen leser, teks en tradisie voortgebring (kyk ook 4 hierbo). In hierdie hermeneutiese sirkel15 antisipeer die leser teksbetekenis maar dit is geen subjektiewe verwagting nie. Dit is eerder 'n vooruitblik bepaal deur wat sy/hy met die tradisie gemeen het. Tradisie (Überlieferung) (in Afrikaans ook "oorlewering") is nie bloot 'n voorwaarde vir die verstaan van 'n teks nie. Deur die verstaansakte kry die hermeneut deel in hoe die tradisie ontvou - en sit hy/sy dit self voort (Gadamer, 1975:277). Die hermeneutiese sirkel maak die leser dus intiem deel van die tradisie as oorleweringsgebeure (Überlieferungsgeschehen) en is nie bloot 'n metodologiese gegewe nie: dit manifesteer as 'n ontologiese struktuurmoment van verstaan (Gadamer, 1975:277). Elders verduidelik Gadamer (1975:286-290) dat die leser 'n verstaanshorison in gesprek met die teks projekteer en daardie horison algaande verskuif en uiteindelik ophef. Verstaan beteken ' $\mathrm{n}$ versmelting van die horisonne van die verlede en die hede tot 'n nuwe

14 Die twee-eenheid van interpretasie en toepassing veronderstel ook 'n twce-ecnheid van uitleg/interpretasie en verstaan (Gadamer, 1975:290-291)

15 Kyk ook Du Plessis (1980:28-29) oor die hermeneutiese sirkel 
horison. Geen teksinterpretasie is ooit "oorspronklik" nie. Interpretasie is altyd die produk van 'n effektief-werksame, historiese bewussyn (wirkungsgeschichtliches Bewußtsein). Vir die leservertolker "ontwikkel" betekenis in 'n proses soortgelyk aan 'n gesprek met die teks waardeur sy/haar vóórverstaan (en vooroordele, soos Gadamer hulle verstaan - kyk 4.4 hierbo) voortdurend bevraagteken, aangepas en dan opnuut weer bevraagteken word (Gadamer, 1975:284-290)

Gadamer se beskrywing van die verstaansproses veronderstel 'n teksstruktuur wat dermate koherent en stabiel is dat dekonstruksie kwalik daarmee vrede sal vind. Dit is egter betekenisvol dat Gadamer, selfs vanuit hierdie "meer konserwatiewe" beredenering, teksbetekenis steeds as (histories) oop en onafgehandel sien. Daar is met ander woorde nie één korrekte betekenis "in", "van" en "vir" 'n teks nie. Die vertolker maak, in gesprek met die teks en as akteur in 'n drama genaamd "tradisie/oorlewering", 'n betekeniskeuse wat vir die besondere situasie die mees toepaslike is. Daardeur word die twee-eenheid van verstaan en toepassing weer eens beklemtoon.

Gadamer se histories gevoelige beskrywing van die verstaansgebeure maak dit duidelik dat geskiedenis (en tradisie) nie bloot te doen het met "wat in die verlede lê nie" maar inderdaad óók in die hede "gemaak word" deur elke verstaansakte wat op sy beurt weer op die verstaanshorison van leserhermeneute in die toekoms verskyn. Vir die regshermeneutiek van belang is dat die verantwoordelikheid vir die maak van keuses in die hede só veronderstel word. Regstoepassings van Gadamer (1975:307-323) se hermeneutiek illustreer hierdie verantwoordelikheid op verskillende maniere.

Eerstens moet daar 'n regstaat wees, want regshermeneutiek is slegs moontlik indien regsvoorskrifte alle lede van die (regs-)gemeenskap op dieselfde wyse bind (Gadamer, 1975:312). Almal moet met ander woorde gelyk wees voor die reg:

[W]o etwa, wie im Absolutismus, der Wille des absoluten Herrschers über dem Gesetz steht, kann es keine Hermeneutik geben, 'da ein Oberherr seine Worte auch wider die Regeln gemeiner Auslegung erklaren kann' ... Die Aufgabe des Verstehens und Auslegens besteht eben nur dort, wo etwas so gesetzt ist, daß es als das Gesetzte unaufhebbar und verbindlich ist (Gadamer, 1975:312).

Gadamer beskryf 'n situasie waar die verklaarde wil van die despoot die vertolking van die hermeneut, byvoorbeeld die regter, blatant oortroef. Die meer subtiele weergawe is die ontduiking van hermeneutiese verantwoordelikheid regtens meesal regterlike verantwoordelikheid - deur agter die "duidelik uitgesproke wil" van die soewerein te skuil. As verskoning word gewoonlik aangevoer dat dit onbehoorlik is vir die "objektiewe juris/regter" om dié wetgewerswil té aktivisties te beperk of uit te brei en só in politieke vaarwaters te beland. In 'n Suid-Afrika waar almal nie gelyk was voor die reg nie, het hierdie oënskynlik 
Dle sakelys vir wetsteksvertolking en die epog van konsttiusionallsme in Suid-Afrika

fatsoenlike óórversigtigtheid gehelp om regters van die doeltreffendste handlangers van die apartheidsregime te maak (Du Plessis, 1986:83-84). Dit het veral duidelik geword namate die politieke klimaat in die laat-tagtiger- en vroeënegentigerjare begin verander het en sommige regters besef het dat konstitusionalisme onafwendbaar was. Plotseling is in sommige hofuitsprake (weliswaar nog 'n minderheid) bevind dat die voorheen duidelik uitgesproke wil van die soewerein nie meer so duidelik was nie, en is demoniese apartheidswette vertolk om iets anders te sê as wat jarelank geglo is hulle in "duidelike en ondubbelsinnige taal" sê (vir voorbeelde hiervan kyk Du Plessis \& Corder, 1994:70 vn. 48)

I weedens verg hermeneutiese verantwoordelikheid, soos Gadamer (1975:312313) dit sien, van die regsvertolker, veral die regter, 'n konkretisering16 van die regsnorm (Konkretisierung des Gesetzes). Konkretisering sluit toepassing in en vereis dikwels normvoltooiing deur aanvulling (Rechtsergänzung). Dít is tipies 'n regterlike verantwoordelikheid. Die regter is egter, soos enige ander lid van die regsgemeenskap, regsgebonde wat beteken dat willekeurige regsbeslissings nie te regverdig is nie: hofuitsprake behoort, regsekerheidsonthalwe, voorsienbaar te wees. En dan maak Gadamer (1975:313) 'n betekenisvolle stelling wat geparafraseerd op die volgende neerkom: regterlike uitsprake kan regsdogmaties of regshermeneuties geregverdig word. In die eerste geval word regsprobleme "opgelos" deur hulle onder algemeen geldende regsnorme en -beginsels tuis te bring (te subsumeer). In die tweede geval word regsprobleme hermeneuties beredder deur normtekste vertolkend te konkretiseer. Die laasgenoemde modus geniet, aldus Gadamer, beslis voorrang.

Dit is 'n derde faset van die regsvertolker se verantwoordelikheid, naamlik om te hermeneutiseer in plaas daarvan om te dogmatiseer. Tekortkominge in die konstitutionele regspraak (constitutional jurisprudence) van Suid-Afrikaanse howe voor 1994 (veral die van die destydse Appèlafdeling van die Hooggeregshof), bevestig die belang van hierdie insig. ${ }^{17}$ Die Appèlhof was in grondwetlike hersieningsake geneig om van "omstrede beslissings" oor grondwetlike (en dus

16 Hy gebruik dieselfde terminologie as Friedrich Muller - kyk hierbo

17 Suid-Afrka het op daardie stadium nie 'n beregbare grondwet met 'n handves van regte gchad nie. Sommige van die sogenaamd onafhanklike TB.V.C.-state het egter wel en dit het geleenthede vir konstitusionele regspraak geskep. 'n Ander baie belangrike bron van konstitusionele regspraak was die beregbare Handves van Fundamentele Regte wat in Aanhangsel 1 tot Proklamasie R. 101 van 17 Junie 1985 vervat was. Die betrokke proklamasie het die funksie van 'n tussentydse grondwet vir die destydse Suidwes-Afrika/Namubië vervul Gedinge waarin die vertolking van bepalings van die Handves van Fundamentele Regte in geskil was, is aanvanklik in die Hooggeregshof van Suidwes-Afrika/Namibiè aanhangig gemaak maar daar was ' $n$ reg van appèl na die destydse Appèlafdeling van die Hooggeregshof in Suid-Afrika 
onvermydelik politieke) kwessies te probeer wegskram. Die verantwoordelikheid om betwiste wetgewing of administratiewe optrede daadwerklik aan tipiese handveswaardes te toets, is met allerlei slim, tegniese beredeneringe - "fatsoenlike" regsdogmatiese argumente, sou mens kon sê - ontduik (vir illustrasies hiervan kyk Du Plessis \& De Ville, 1993a:67-73). Só is regshermeneutiese moontlikhede wat in antisipasie van 'n komende konstitusionalisme ontgin kon word, onderdruk en is nogeens probeer om 'n tradisioneel regterlike formalisme in Suid-Afrika respektabel te laat lyk.

Wat Gadamer oor die verhouding tussen regterlike verantwoordelikheid en die aard van die regsorde sê, beklemtoon wat ons daadwerklik in Suid-Afrika ervaar het, naamlik dat die kwaliteit van regshermeneutiek regstreeks afhanklik is van die kwaliteit van regering soos gemeet aan standaarde van regstaatlikheid (en dus ook konstitusionalisme). Dat in Suid-Afrika wetstekshermeneutiek dié verskyningsvorm van regshermeneutiek is wat waarskynlik van die meeste "meer moderne hermeneutiese sienings" verstoke gebly het, is nie verbasend nie. Die despotiese apartheidsregime het immers vrylik van wette gebruik gemaak om hulle sosiale eksperiment en daarmee gepaardgaande sekurokrasie op die bevolking af te dwing. Hoe duideliker, ondubbelsinniger en meer despoties die soewerein beveel het, hoe meer verantwoordelikheidsloos, irrelevant en straks gedienstig het regterlike wetshermeneute wette "vertolk".

\section{Slotperspektief: is die agenda af te handel?}

'n Sakelys sê wat bespreek gaan word. Dit is nie die bespreking self nie. Dit is ook nie naastenby die aksieplan wat tot stand (kan) kom as gevolg van die bespreking nie. Hierdie artikel is doelbewus in 'n sakelystrant geskryf. Dit is geregverdig want selfs die sakelys vir 'n transformasie van wetsteksvertolking in 'n konstitusionalistiese Suid-Afrika is nog nie voorheen opgestel nie. Bring die sakelys in hierdie artikel ' $n$ mens verder? Dít word ten slotte beoordeel aan die hand van die drie sentrale ideëmotiewe wat in die inleidingsparagraaf (1 hierbo) aangestip is, naamlik:

(i) Wetstekste is nie selfstandige entititeite waarin 'n vaste betekenis opgesluit lê nie.

(ii) Die verskeidenheid moontlike wetsteksbetekenisse word, vanweë die kenmerkende geldingsgerigtheid van die teksgenre beperk. Die wetsteksvertolker staan dus onvermydelik voor 'n keuseverantwoordelikheid.

(iii) Die epog van konstitusionalisme plaas 'n transformasionele ondermyning van tradisionele sekerhede oor wetsuitleg op die sakelys (en takelys) van vernuwende wetsteksvertolking. 
Motief (iii) hierbo is die maklikste item op die sakelys om te hanteer. Dit kan trouens selfs pret wees om valse sekerhede te ondermyn! Dit maak nie regtig saak of dit leë of gevaarlike sekerhede is nie. Die verwagting dat daar betekenis in 'n teks is, is byvoorbeeld leeg. Die sekerheid dat hierdie nie-aanwesige betekenis met die "regte" interpretasiestegnieke "neutraal" (en vooroordeelloos) uit die teks opgediep kan word, kan 'n gevaarlike maskering van 'n chroniese magsonewewig in die samelewing wees. Die volgende tradisionele sekerhede oor wetsteksvertolking is in hierdie artikel, regstreeks of onregstreeks, ondermyn of anders ten minste in vraag gestel:

- 'n Wetsteks put betekenis uit die bedoeling van die wetgewer.

- Taal, as konstante en stabiele betekenisgewer, "dra" betekenis. Dit is die medium waardeur die betekenis wat die wetgewer in die wetsteks "geplaas" het, oorgedra word.

- Ekspertvertolkings van wetstekste is wesenlik "beter" of meer gesaghebbend as nie-ekspertvertolkings.

- Vooroordele by wetsvertolkers is per definisie onbehoorlik.

- En dan laastens die verwagting van 'n nuwe regshermeneutiese ortodoksie: doeldienende uitleg (purposive interpretation) is 'n eietydse, with itfenomeen, kenmerkend van die epog van konstitusionalisme.

Die heel verreikendste (en waarskynlik ook die hardnekkigste) sekerheid wat deurgaans in hierdie artikel ondergrawe is, is dat wetstekste selfstandige entititeite is waarin 'n vaste betekenis opgesluit lê (kyk ook ideëmotief (i) hierbo). Wetsteksinterpretasie (wetsuitleg sowel as grondwetsuitleg) is veel meer van ' $n$ heen-en-weer-spel tussen ' $n$ magdom betekenaars - en veel minder van ' $n$ reëlgedrewe prosedure gerig op 'n vasstaande teks-met-betekenis - as wat SuidAfrikaanse juriste tradisioneel vermoed het. Hierop is ideëmotief (ii) hierbo egter 'n werkdadige korrektief: Daar is, gegee die distinktiewe geldingsgerigtheid van wetstekste, besliste spelreëls wat wetsteksbetekenisse beperk. Wetsteksvertolking is nie ongebreidelde free for all-willekeur nie, al is die betekeniskeusemoontlikhede ook hoe ruim en al is die regstelsel (sóós taal) nog so kompleks. Bestendigheid en voorsienbaarheid in hierdie komplekse sisteem, hoe minimaal ook al, is vir die regsgeleerde wetsteksvertolker kardinaal, omdat die teksgenre hom of haar in die laaste instansie 'n keuseverantwoordelikheid oplê.

Bloot retories bekyk, is dit moontlik om 'n wye verskeidenheid vertolkings van 'n wetsteks te regverdig. In regsgeleerde diskoerse oor moontlike wetsteksbetekenisse laat dít alleen egter nie toereikend reg geskied aan die tipiese geldingsgerigtheid van die wetsteks nie. 'n Wetsteksvertolker kan byvoorbeeld 
nie sê dat 'n wet dit of dát beteken omdat "dit is hoedat ek vandag voel nie" of omdat "dit my politieke sentimente die beste bevredig nie". Daar is 'n matriks van vertolkingslegitimiteit of -geloofwaardigheid wat 'n sekere soort retoriek veroorloof en 'n ander soort nie. "Matriks/matrys" beteken onder meer "dit waaruit iets voortkom" of "dit wat iets omvat en daaraan vorm gee" (Simpson \& Weiner, 1989:476-477; Neilson et al., 1946:1515 en Van Schalkwyk et al., 1996:193). In Suid-Afrika het die epog van konstitusionalisme hierdie matriks van vertolkingslegitimiteit aansienlik verryk. Sekere argumente wat voorheen "ontoelaatbaar" en selfs ondenkbaar sou wees, is nou byvoorbeeld "toelaatbare retoriek" in regsgeleerde diskoerse oor wetsteks- en veral grondwetsvertolking. Sonder 'n vertolkingstradisie het so 'n matriks egter nie legitimiteit nie. Een van die hoofitems op die sakelys van wetsteksvertolking in Suid-Afrika is 'n diskussie oor hoedat konstitusionalisme die matriks van vertolkingslegitimiteit (kan) verryk, sonder om die tradisie te emaskuleer.

Regsgeleerde wetsteksvertolkers is onvermydelik konserwatief, nie in die sin van "onafwendbaar reaksionêr" of "noodwendig in verset teen vernuwing" nie, maar "konserverend" (of "bewaringsbewus") binne die sisteem waarin hulle werk. Die konsepte "sisteem" en "matriks" veronderstel hierdie konserwatiwiteit deur die oplê van 'n bewaringsplig. Die konserverende element in diskoerse oor wetsteksvertolking maak van common law-reëls en -vermoedens van wetsuitleg kandidate om vertolkingskanons te wees wat wetsteksbetekenisse beperk. In hierdie rol is hulle egter nie sjibbolette wat toegang tot dié een regte betekenis inherent aan 'n wetsteks verleen nie - so 'n betekenis bestaan nie! - maar deurwagters wat slegs sekere (moontlike) teksbetekenisse vir regsgebruik deurlaat. Baie van hierdie kanons sal ingrypend herverstaan en ook geherformuleer moet word - nóg ingrypender as wat ekself voorheen (met beperkter insigte as tans) probeer het (Du Plessis, 1986:54-60). Hulle sistematiese herkontekstualisering kan ook verder help om sin aan hulle gebruik in 'n nuwe hoedanigheid te gee. Hiermee word bedoel dat hulle byvoorbeeld tuisgebring kan word onder C.F. von Savigny (1840:206-330) se vier sogenaamde "metodes van regsinterpretasie" wat op die Europese vasteland veelal vir wets- en grondwetsvertolking aangewend word. Dié vier metodes (en dit is nie presies soos Von Savigny hulle verduidelik nie) is die volgende (Du Plessis, 1998:13-16):

- grammatikale interpretasie wat konsentreer op die wyse waarop taal toegang tot die betekenismoontlikhede van 'n wetsteks gee;

- sistematiese interpretasie wat probeer om 'n spesifieke bepaling in die lig van die teksgeheel te verstaan (in common law-jargon heet dit die ex visceribus actus-benadenng, dit wil sê 'n opdiep van betekenis "uit die ingewande van die wet"); 
- teleologiese interpretasie wat 'n wetsbepaling verstaan in die lig van die doel wat dit nastreef oftewel aan die hand van die ratio van die wet (dit is die Engelse mischief rule in 'n ietwat ander gestalte en dit is ook purposive interpretation), en

- historiese interpretasie wat, kort gestel, die wetsteks vir verstaansdoeleindes histories situeer.

Hedendaags word regsvergelykende interpretasie ook tot hierdie lys toegevoeg.

Du Toit (1998:44-45) waarsku dat hierdie Savigniaanse metodes in die spinnerakke van 'n verouderde (vroeg-negentiende-eeuse) hermeneutiek verstrik is. Toegegee, dit is so indien 'n mens jou klakkeloos-onnadenkend op hulle sou beroep. Vir bewaringspligtige regskonserwatiste, wars van filosofiese treffersparades, kan die idees van 'n outoriteit uit die geskiedenis, met die statuur van 'n Von Savigny, egter ook ankers vir 'n transformasie van hulle vertolkingstategieë wees. Vanselfsprekend moet hierdie idees ook vlerke kry en staan 'n ingrypende herbesinning oor die hedendaagse gebruik van die Savigniaanse metodes (aan "meer moderne hermeneutiese sienings" georiënteer) in vet letters op die sakelys van wetsteksvertolking geskryf. Die interessante moontlikhede hiertoe, word in hierdie artikel nie verder ontgin nie.

Hermeneutiese verantwoordelikheid is 'n historiese verantwoordelikheid - 'n verantwoordelikheid in maar ook teenoor die geskiedenis. Die konkretiseringseis situeer die wetsteksvertolker in 'n geskiedenis, 'n "gebeurende werklikheid", waarvan Martin Heidegger (1981:34) die volgende sê:

Geschichte als Geschehen ist das aus der Zukunft bestimmte, das Gewesene übernehmende Hindurchandeln und Hindurchleiden durch die Gegenwart. Diese ist es gerade, die in Geschehen verschwindet. ${ }^{18}$

As deelgenote aan die epog van konstitusionalisme sê dít in die eerste plek vir wetstekshermeneute in Suid-Afrika dat die juridiese grondtekste van dié epog, veral die Grondwet, die geskiedenis van Suid-Afrika tegelyk vertel en skryf. Grondwetsvertolking, en wetsvertolking in die lig van die Grondwet, vorder die betaling van 'n ereskuld waardeur 'n verlede van onreg oorkom moet word deur:

- dit hermeneuties “oor te neem", dit te agterhaal, en

18 In 'n amptelike Engelse vertaling lyk hierdie haas onvertaalbare uitspraak só (Heidegger, 1961:36):

History as happening is an acting and being acted upon which pass through the present, which are determined from out of the future and which take over the past. It is precisely the present that vanishes in happening 
- algaande by die gebreke daarvan verby te leef - dit verby te steek en agter te laat.

Dit is die verantwoordelikheid teenoor die geskiedenis.

Die verantwoordelikheid in die geskiedenis is hermeneutiese singewing aan dit wat uit die toekoms bestem kan word, naamlik die verwagting van 'n regverdiger samelewing met 'n regverdiger regsorde. Diskoerse hieroor sal die moeite werd wees alleen indien kritiese besinning oor wetsteksvertolking toenemend op die wydste moontlike verskeidenheid regsgeleerde sakelyste in Suid-Afrika kom. Indien hierdie artikel in slegs 'n beskeie mate dáártoe kan bydra, is dit 'n waardige huldigingsblyk aan 'n gewaardeerde doyen van ons epog van konstitusionalisme.

\section{Bibliografie}

AUSTIN, John. 1885. Lectures on jurisprudence. Londen : Murray.

BALKIN, J M. 1987 Deconstructive practice and legal theory. The Yale Law Journal, 96(4):743-786

BALKIN, J.M. 1994. Transcendental deconstruction, transcendent justice. Michigan Low Review, 92(5) 1131-1186

BETTERMAN, Karl August. 1986. Die verfassungskonforme Auslegung: Grenzen und Gefahren. Heidelberg : Muller

BÖNNINGHAUS, Julia E. 1998. Constitutional interpretation in South Africa. Bellville : Universiteit van Wes-Kaapland. (LL.M.-skripsie.)

CAPUTO, John D., ed. 1997. Deconstruction in a nutshell: A conversation with Jacques Derrida New York : Fordham University Press.

CILLIERS, Paul. 1998. Complexity and postmodernism: Understanding complex systems London/New York : Routledge.

COWEN, D.V. 1976. Prolegomenon to a restatement of the principles of statutory interpretation. Tydskrif vir die Suid-Afrikaanse Reg, 1976(2):131-176.

COWEN, D.V. 1980. The interpretation of statutes and the concept of "the intention of the legislature". Tydskrif vir Hedendaagse Romeins-Hollandse Reg, 43(4):374-399.

CRAIES, W F. 1971. Craies on statute law. 7de uitg. deur S.G.G. Edgar. London : Sweet \& Maxwell

CROSS, Rupert. 1995 Statutory interpretation. 3de uitg. deur John Bell and George Engle. London/Dublin/Edinburgh : Butterworths.

DAVID, René \& BRIERLY, John E C. 1985 Major legal systems in the world today. 3de uitg London: Stevens

DE VILLE, J 1997. Eduard Fagan in context. S.A. Publiekreg, 12(2):493-513.

DE VILLE, J. 1999. Meaning and statutory interpretation. Manuskrip van 'n artikel wat gepubliseer word in die Tydskrif vir Hedendaagse Romeins-Hollandse Reg, 62.

DE WAAL, Johan, CURRIE, lain \& ERASMUS, Gerhard. 1999. The Bill of Rights handbook 2de uitg. Kenwyn : Juta

DERRIDA, Jacques 1992 Force of law: The "mystical foundation of authority". (In Cornell, Drucilla, Rosenfeld, Michel \& Carlson, David Gray, eds. Deconstruction and the possibility of justice. New York/London : Routledge. p. 3-67.)

DERRIDA, Jacques. 1981. Positions. Chicago : University of Chicago Press.

DEVENISH, G.E 1992. Interpretation of statutes. Kaapstad/Wetton/Johannesburg : Juta 
DREIER, Ralf. 1976. Zur Problematik und Situation Verfassungsinterpretation. (In Dreier, Ralf \& Schwegmann, Friedrich, eds. Probleme der Verfassungsinterpretation. BadenBaden : Nomos. p. 13-47.)

DUGARD, John. 1971. The judicial process, positivism and civil liberty. The South African Law Journal, 88(2): 181-200

DUGARD, John. 1978. Human rights and the South African legal order. Princeton, New Jersey : Princeton University Press.

DUGARD, John. 1981. Some realism about the judicial process and positivism - a reply. The South African Law Journal, 98(3):372-387.

DU PLESSIS, Lourens M. 1986. The interpretation of statutes. Durban : Butterworths

DU PLESSIS, Lourens M. 1996. Legal academics and the open community of constitutional interpreters. South African Joumal on Human Rights, 12(2):214-229.

DU PLESSIS, Lourens M. 1997. Wetsuitleg in Suid-Afrika in die lig van die aanvaarding van 'n menseregtehandves. Ongepubliseerde verslag oor die aanwending van 'n SWOtoekenning vir gevestigde navorsers. Stellenbosch

DU PLESSIS, Lourens M. 1998. The jurisprudence of interpretation and the exigencies of a new constitutional order in South Africa. Acta Juridica, 8-20

DU PLESSIS, Lourens \& CORDER, Hugh. 1994. Understanding South Africa's transitional Bill of Rights. Kenwyn : Juta.

DU PLESSIS, Lourens M. \& DE VILLE, J.R 1993a. Bill of rights interpretation in the South African context (1): Diagnostic observations. Stellenbosse Regstydskrif, 4(1):63-87.

DU PLESSIS, Lourens M. \& DE VILLE, J R. 1993b. Bill of rights interpretation in the South African context (2): Prognostic observations. Stellenbosse Regstydskrif, 4(2):199-218.

DU PLESSIS, Lourens M. \& DE VILLE, J R. 1993c. Bill of rights interpretation in the South African context (3): Comparative perspectives and future prospects. Stellenbosse Regstydskrif, 4(3):356-393.

DU TOIT, H.L. 1998. The contribution of hermeneutics and deconstruction to jurisprudence A response. 1998. Acta Juridica, 41-57

EHMKE, Horst. 1963. Prinzipien der Verfassungsinterpretation. Veroffentlichen der Vereinigung der Deutsches Staatsrechtslehrer, 20:53-98.

FELDMAN, Stephen M. 1996. The politics of postmodern jurisprudence. Michigan Law Review, 95(1): 166-202.

FISH, Stanley. 1989. Doing what comes naturally. Change, rhetoric, and the practice of theory in legal studies. Oxford : Clarendon Press

FORSYTH, C. \& SCHILLER, J. 1981. The judicial process, positivism and civil liberty II. The South African Law Journal, 98(2):218-230

FOUCAULT, Michel. 1990. The history of sexuality, Volume 1: An introduction. Penguin Books

GADAMER, H-G. 1976. Philosophical hermeneutics. Berkeley : University of California Press.

GADAMER, Hans-Georg 1975. Wahrheit und Methode. Grundzüge einer philosophischen Hermeneutik. 4de uitg. Tubingen : Mohr

HÄBERLE, Peter. 1978. Verfassung als offentlicher Prozeß. Materialen zu einer Verfassungstheorie der offenen Gesellschaft. Berlyn : Duncker \& Humblot

HEIDEGGER, Martin 1961. An introduction to metaphysics. New York : Anchor Books.

HEIDEGGER, Martin. 1981. Einfuhrung in die Metaphysik. Tubingen : Niemeyer.

HERDEGEN, M. 1990. The activist judge in a "positivistic" environment. Stellenbosse Regstydskrif, 1(3):336-347.

HUNT, Alan \& WICKHAM, Gary. 1994. Foucault and law: Towards a sociology of law as governance. London/Boulder, Colorado : Pluto Press. 
LITOWITZ, Douglas. 1995. Foucault on law: Modernity as negative utopia. Queens Law Journal, 21(1): 1-37.

MAGIERA, Siegfried 1983. The interpretation of the Basic Law. (In Starck, Christian, ed. Main principles of the German Basic Law. Baden-Baden : Nomos. p. 89-106.)

MAXWELL, P.B 1976. The interpretation of statutes. 12de uitg deur P.St.J. Langan Bombay : Tripathi.

McKEON, R. 1990. Freedom and history and other essays. Chicago : University of Chicago Press.

MULLER, Friedrich. 1997. Juristische Methodik. 7de uitg. Berlyn : Duncker \& Humblot

NICOLSON, Donald. 1992. Ideology and the South African judicial process - Lessons from the past. South African Journal on Human Rights, 8(1):50-73.

NEILSON, William Allan, KNOTT, Thomas A. \& CARHART, Paul W., eds. 1946. Webster's new international dictionary of the English language Vol. I. Springfield, Massachusetts Merriam

RAUTENBACH, I M. 1995. Algemene bepalings van die Suid-Afrikaanse handves van regte. Durban : Butterworths.

ROSENFELD, Michel. 1992. Deconstruction and legal interpretation: Conflict, indeterminacy and the temptation of the new legal formalism. (In Cornell, Drucilla, Rosenfeld, Michel \& Carlson, David Gray, eds. Deconstruction and the possibility of justice. New York/London : Routledge. p. 152-210.)

RUSSELL, J Stuart. 1986. The Critical Legal Studies challenge to contemporary mainstream legal philosophy. Ottawa Law Review, 18(1):1-24.

SCHNEIDER, Peter. 1963. Prinzipien der Verfassungsinterpretation Veröffentlichen der Vereinigung der Deutsches Staatsrechtslehrer, 20:1-52

SCHUPPERT, Gunnar Folke. 1988. Self-restraint der Rechtsprechung. Uberlegungen zur Kontrolldichte in der Verfassungs- und Verwaltungsgerichtarbeit. Deutsches Verwaltungsblat, 103(24): 1191-1200

SIMPSON, J.A. \&. WEINER, E S.C., eds. 1989. The Oxford English dictionary. Vol. 9. 2de uitg. Oxford : Clarendon Press.

STEYN, L.C. 1981. Die uitleg van wette. 5de uitg. Kaapstad/Wetton/Johannesburg : Juta

VAN BLERK, A 1984. The genesis of the "modernist-purist" debate. Tydskrif vir Hedendaagse Romeins-Hollandse Reg, 47(3):255-279

VAN DEN BERGH, N.J.C. 1982. Die betekenis van die strukturele hermeneutiek vir die uitleg van wette. Bloemfontein : UVS. (LL.D.-proefskrif.)

VAN DER WALT, Johan. 1998. The language of jurisprudence from Hobbes to Derrida (the latter's quest for an impossible poem). Acta Juridica, 61-96

VAN SCHALKWYK, D.J. et al., eds. 1996. Woordeboek van die Afrikaanse taal: Tiende deel. Stellenbosch : Buro van die W A T.

VON SAVIGNY, Friedrich Carl. 1840. System des heutigen römischen Rechts I. Berlyn Veit.

WIEACKER, F. 1967. Privatrechtsgeschichte der Neuzeit. 2de uitg Gottingen : Vandenhoeck.

WITTEVEEN, Willem Johannes. 1988. De retoriek in het recht. Over retorika en interpretatie, staatsrecht en demokratie Zwolle : Tjeenk Willink.

WOLFF, Hans J., BACHOF, Otto \& STOBER, Rolf. 1994. Verwaltungsrecht. Ein Studienbuch 10de uitg München : Beck.

\section{Wette}

Grondwet van die Republiek van Suid-Afrika, Wet 200 van 1993.

Grondwet van die Republiek van Suid-Afrika, Wet 108 van 1996 
Wet op Arbeidsverhoudinge, Wet 66 van 1995

\section{Hofsake}

Cabinet for the Territory of South West Africa v. Chikane, 1989 (1) S.A. 349 (A)

Government of the Republic of Bopmuthatswana and Others v. Segale, 1990 (1) S.A 343

(B A D ).

Jaga v. Donges, 1950 (4) S.A. 653 (A)

S. v. Zuma and others 1995(4) B.C.L R. 401 (S.A) 